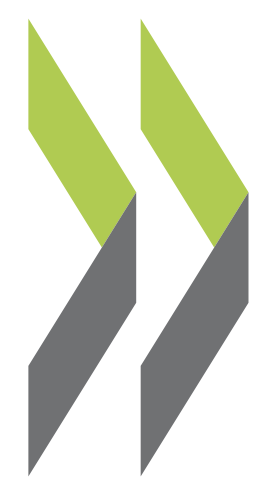

OECD Economics Department Working Papers No. 1376

Boosting productivity in Mexico through integration into global value chains

\section{Sean Dougherty,}

Julien Reynaud 
Organisation de Coopération et de Développement Économiques

Organisation for Economic Co-operation and Development

03-Mar-2017

ECONOMICS DEPARTMENT

English - Or. English

BOOSTING PRODUCTIVITY IN MEXICO THROUGH INTEGRATION INTO GLOBAL VALUE CHAINS

ECONOMICS DEPARTMENTS WORKING PAPERS No. 1376

By Sean Dougherty and Julien Reynaud

OECD Working Papers should not be reported as representing the official views of the OECD or of its member countries. The opinions expressed and arguments employed are those of the author(s).

Authorised for publication by Alvaro Pereira, Director, Country Studies Branch, Economics Department.

All Economics Department Working Papers are available at www.oecd.org/eco/workingpapers.

JT03409868

Complete document available on OLIS in its original format

This document and any map included herein are without prejudice to the status of or sovereignty over any territory, to the delimitation of international frontiers and boundaries and to the name of any territory, city or area. 
OECD Working Papers should not be reported as representing the official views of the OECD or of its member countries. The opinions expressed and arguments employed are those of the author(s).

Working Papers describe preliminary results or research in progress by the author(s) and are published to stimulate discussion on a broad range of issues on which the OECD works.

Comments on Working Papers are welcomed, and may be sent to OECD Economics Department, 2 rue André-Pascal, 75775 Paris Cedex 16, France, or by e-mail to eco.contact@oecd.org.

All Economics Department Working Papers are available at. www.oecd.org/eco/workingpapers

This document, as well as any data and map included herein, are without prejudice to the status of or sovereignty over any territory, to the delimitation of international frontiers and boundaries and to the name of any territory, city or area.

The statistical data for Israel are supplied by and under the responsibility of the relevant Israeli authorities. The use of such data by the OECD is without prejudice to the status of the Golan Heights, East Jerusalem and Israeli settlements in the West Bank under the terms of international law.

Latvia was not an OECD Member at the time of preparation of this publication. Accordingly, Latvia does not appear in the list of OECD Members and is not included in the zone aggregates.

\section{(C) OECD (2017)}

You can copy, download or print OECD content for your own use, and you can include excerpts from OECD publications, databases and multimedia products in your own documents, presentations, blogs, websites and teaching materials, provided that suitable acknowledgment of OECD as source and copyright owner is given. All requests for commercial use and translation rights should be submitted to rights@oecd.org 


\section{ABSTRACT/RÉSUMÉ}

\section{Boosting productivity in Mexico through integration into Global Value Chains}

Mexico's structural reforms are already boosting productivity, but more can be done. This paper focuses on issues that have led to the success of the "modern" Mexico, and have led to difficulties with the "traditional" Mexico. These include the success of Global Value Chains (GVCs) in advancing the trade integration and linkages of key sectors, as well as how competition problems, excessive local regulation, and weak legal institutions have led to misallocation across firms. This paper examines in particular Mexico's successful integration into GVCs. OECD research suggests that GVC participation can bring economic benefits in terms of productivity, diversification and sophistication of production. Understanding what drives integration into GVCs provides policy guidance to support a wider integration.

This Working Paper relates to the 2017 OECD Economic Survey of Mexico

(www.oecd.org/eco/surveys/economic-survey-mexico.htm).

JEL classification: F14, F23, F68, L16, O24

Keywords: productivity, international trade, global value chains, competition, misallocation

$* * * * * * * * * * * * * * * * * * * * * * *$

\section{Augmenter la productivité au Mexique via à l'intégration aux chaînes de valeur mondiales}

Les réformes structurelles récemment mises en place au Mexique ont un impact positif sur la productivité, mais il est possible de faire davantage. Ce document de travail se concentre sur les facteurs qui ont conduit au succès du Mexique «moderne» et ont entraîné les difficultés du Mexique «traditionnel». Ces facteurs comprennent notamment l'intégration réussi aux chaînes de valeur mondiales (CVM) via la promotion de l'intégration commerciale et les liens entre secteurs clés, ainsi que les problèmes de concurrence, de réglementation locale excessive et la faiblesse des institutions juridiques qui conduisent à une mauvaise allocation des facteurs de production. Ce document de travail examine en particulier l'intégration réussie du Mexique aux CVM. Les recherches de l'OCDE dans ce domaine suggèrent que la participation aux CVM peut apporter des avantages économiques en termes de productivité, de diversification et de sophistication de la production. La compréhension des facteurs d'intégration aux CVM peut donc supporter les politiques visant à une intégration plus large.

Ce Document de travail se rapporte à l'Étude économique de l'OCDE du Mexique, 2017

(www.oecd.org/fr/eco/etudes/etude-economique-mexique.htm).

Classification JEL : F14, F23, F68, L16, O24

Mots clés : productivité, commerce international, chaînes de valeur mondiales, concurrence, allocation des facteurs de production 


\section{TABLE OF CONTENTS}

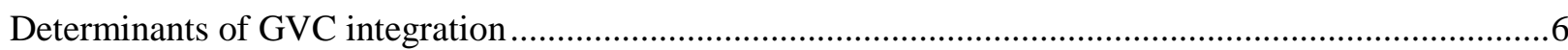

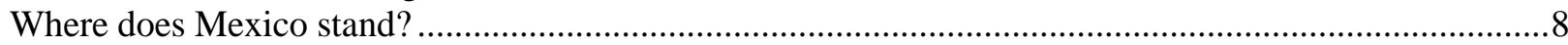

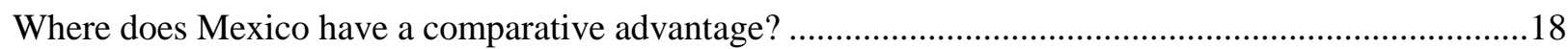

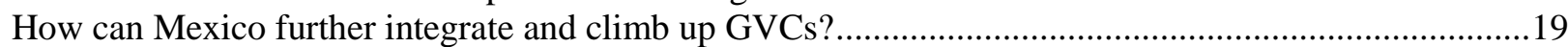

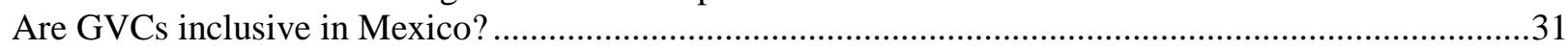

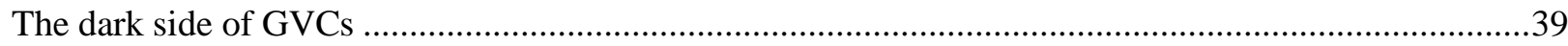

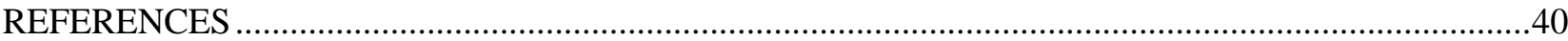

\section{Tables}

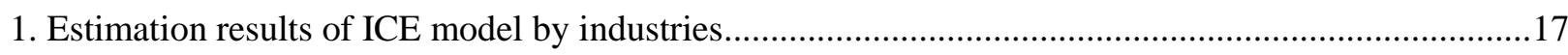

2. Gains from a more efficient allocation of production factors ..............................................................38

\section{Figures}

1. Productivity is picking up in some parts of the economy …...............................................................

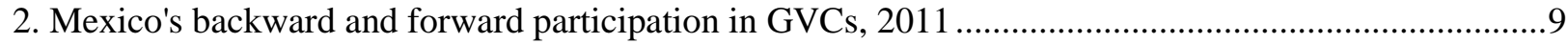

3. Backward GVC participation ratio: relative contribution of policy and non-policy factors...................10

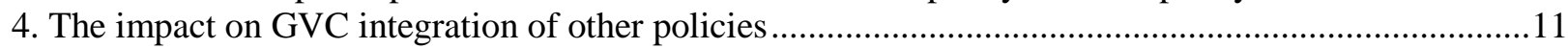

5. Mexico's participation in GVCs, share of intermediates in total trade of manufactured goods and

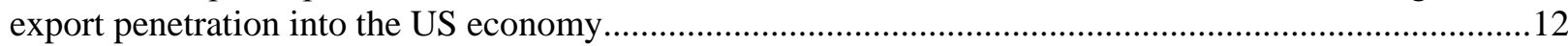

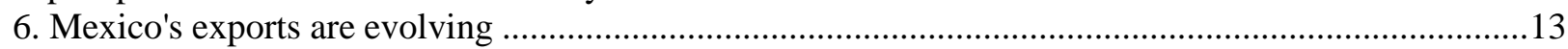

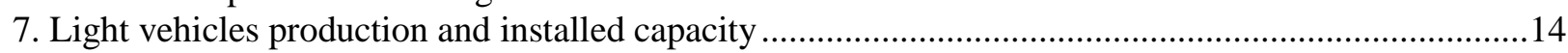

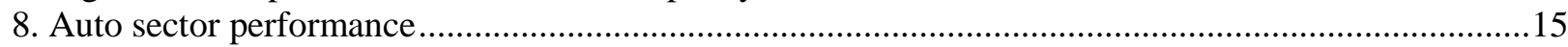

9. Mexico's backward and forward participation to GVCs in selected sectors vs peer OECD countries .16

10. Projected 2014 backward GVC integration in manufacturing industries (ICE) .................................17

11. Sectorial complexity measures vs backward participation to GVC (ICE) .......................................18

12. Backward GVC participation and labour productivity vs revealed comparative advantage (RCA)....19

13. Mexico Knowledge Economy Index (KEI) is the lowest among OECD countries .............................20

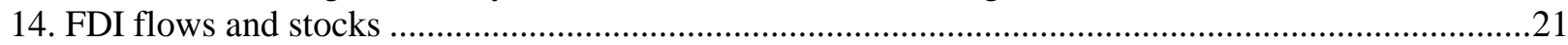

15. FDI, backward integration to GVCs and labour productivity ........................................................22

16. Foreign investment and service trade barriers remain high in some sectors ......................................22

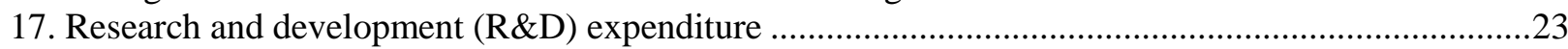

18. Sectors spending more in $R \& D$ are more integrated in GVCs and enjoy higher labour productivity .24

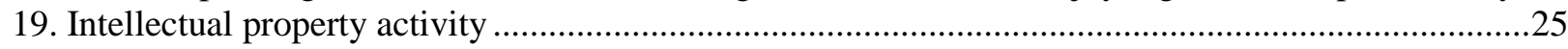

20. ISO certified industries are more backward integrated in GVCs....................................................26

21. Sectors with higher educated workers are more productive and more integrated in GVCs ...............26

22. Mexico's share of engineering graduates is high but lags behind in tertiary and vocational ...............28

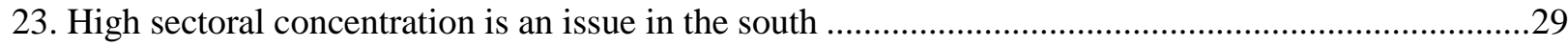

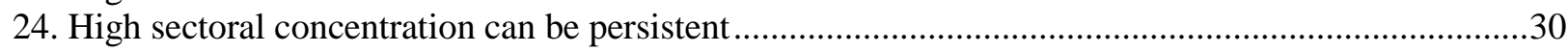

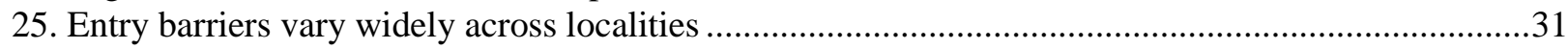

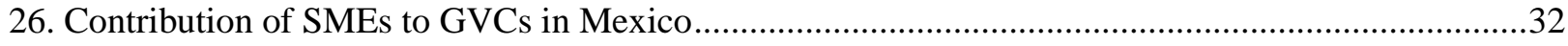

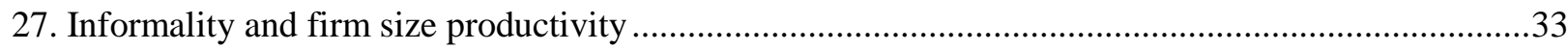




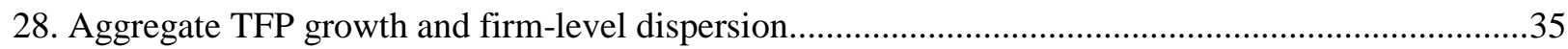

29. More efficient factor allocation could shift out the productivity distribution ....................................38

30. Vulnerability to demand shocks in GVCs, by economy ..................................................................39

\section{Boxes}

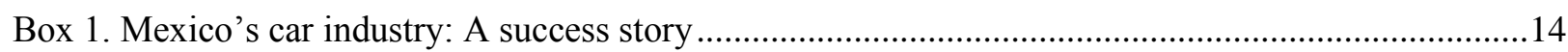

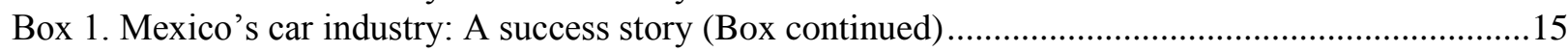

Box 2. Projecting Mexico's backward integration to GVCs in 2014 .....................................................17

Box 3. How does Mexico's productivity dispersion compare with China's? ............................................35

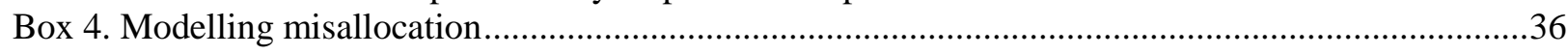




\title{
BOOSTING PRODUCTIVITY IN MEXICO THROUGH INTEGRATION INTO GLOBAL VALUE CHAINS
}

\author{
By Sean Dougherty and Julien Reynaud ${ }^{1}$
}

Following the Mexican government's wide-ranging structural reforms since 2012, according to OECD estimates, total factor productivity growth has turned positive and picked up (Figure 1, Panel A). Nevertheless, success has not spread all over the country and large income gaps persist between the highly productive modern economy and the low-productivity traditional one. Mexico's most productive firms and sectors are performing very well - such as auto exports - but the vast majority of firms and sectors are still struggling. Total factor productivity growth, estimated using detailed sector-level production functions, has accelerated during the most recent period for the top $10 \%$ of industries, while the long decline in productivity in the remaining $90 \%$ of sectors has been arrested (Figure 1, Panel B).

Figure 1 Productivity is picking up in some parts of the economy
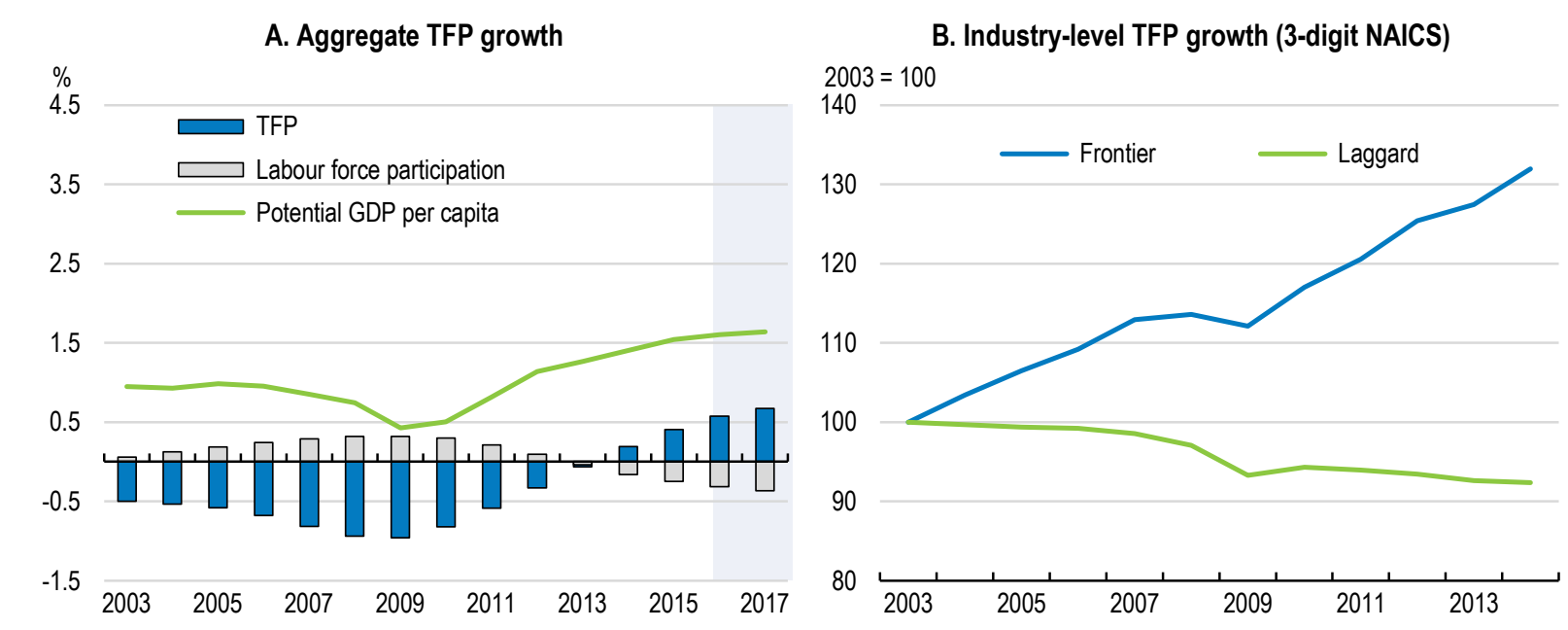

Source: OECD Economic Outlook database, OECD analysis of KLEMS data from INEGI

\section{Determinants of GVC integration}

The emergence of GVCs has brought to consumers products that are increasingly complex bundles of inputs from multiple origins. GVCs are often complex networks involving multi-directional flows of material inputs, services and personnel, ownership of assets via foreign direct investment (FDI) in a cross-

\footnotetext{
${ }^{1}$ Sean Dougherty is a Senior Economist at the OECD, email: sean.dougherty@oecd.org, while Julien Reynaud is an Economist at the OECD and currently on leave from the International Monetary Fund, email: jreynaud@imf.org. Feedback from the Economic and Development Review Committee (EDRC) is appreciated, especially from the EDRC Chairman William White and examiners Alberto Soler Vera (Spain) and Tamara Trotman (Canada), as were comments from OECD colleagues Koen De Backer and Jonathan Timmis (both from the Directorate for Science, Technology and Innovation), Sean Ennis (Directorate for Financial and Enterprise Affairs), Robert Ford, Patrick Lenain, Alvaro Pereira and Muge Adalet McGowan (all from the Economics Department), as well as Guillermo García (Mexico's Ministry of Economy), Fernando Ávila, Luis Madrazo, Jesus Puente, and Juan Rebolledo (all from Mexico's Ministry of Finance). Inputs to the paper from Octavio Escobar (Paris School of Business) and Adrien Moutel are gratefully acknowledged, as well as editorial assistance from Raquel Paramo (both OECD).
} 
border context, enforcement of contracts and standards, encompassing transfer of technology and protection of intellectual property (IPR).

GVC participation can be captured with indicators of backward and forward participation. Backward participation in GVCs is defined as the share of foreign value added in a country's gross exports. Forward participation is defined as the share of domestic value added embodied in foreign countries' exports. Improving backward linkages has many benefits. It entails import competition, in particular in manufacturing and services, and accelerates the reallocation of domestic resources towards the most competitive firms. Backward integration also facilitates the diffusion of knowledge either indirectly through learning from suppliers or directly via knowledge spillovers from foreign direct investment (FDI). Improving forward integration, that is the production of intermediate inputs used in other countries' exports, increases the potential market, leverages the use of human capital and natural resources, and, as a result, contributes to growing economic activity.

The development of GVCs has been driven by the search for competitive intermediate inputs. With more geographically-fragmented production processes, additional costs accrue, notably at the border. But many costs accumulate long before the border is reached, as GVCs have large domestic arms (De Backer and Miroudot, 2013). Under $10 \%$ of trade costs are estimated to be tariffs, with $10-30 \%$ represented by natural trade costs (i.e., geographical and cultural factors) and the remaining 60-80\% relating to indirect costs of trade procedures, maritime connectivity and services, regulatory environment, currency fluctuations and availability and use of ICT services (UNESCAP, 2014).

The scope for government intervention is therefore large. Governments can facilitate border and "preborder" environments. Border costs - those mostly related to customs procedures - are predominantly regional and thus involve government's foreign policy (OECD, 2015d). Pre-border costs are related to costs of use and the quality of infrastructure and logistics services, regulatory burdens, etc. One example of relevant policy intervention is the creation of special economic zones, such as have recently been introduced in Mexico's poorer southern states, with the aim to provide investment incentives, improve infrastructure and streamline regulatory processes. An economy's state of development determines its capacity to produce valuable intermediates to be used by both domestic and foreign countries' exporters, and is also a good proxy to the institutional setup to do business. Typically, the relative quality of productive and human capital is expected to be negatively correlated with backward participation, while it is expected to be positively correlated with forward linkages. Industry composition also affects GVC participation. For instance, services exports contain less foreign value added than manufacturing exports.

But like trade openness, integration into GVCs depends also on factors that are not directly related to economic policies. Legal origins and common language are robust determinants of bilateral trade linkages in gravity-type models. Natural endowments also play a central role in GVC integration. Countries with low endowments in commodities typically have higher backward integration while high endowments increases forward integration. Geographical location is also an important determinant of trade and GVC integration, as it is a good proxy for trade costs. Firms also locate in leading-edge countries close to the technology frontier, in order to benefit from the diffusion of advanced technologies (Griffith et al., 2004). Many studies nevertheless discuss the fact that distance may affect both the numerator and denominator of backward and forward participation, and conclude that the impact of distance is therefore less certain. 
Mexico is among the most open large economies in the world, and the country's free trade openness policy has yielded tremendous benefits over the last two decades. Twelve free trade agreements have been signed with 46 countries, which benefit Mexico's trade directly and also indirectly, as FDI inflows led firms to strategically locate in Mexico rather than other regions, in order to penetrate North American markets. Mexico is relatively well-endowed given its location, the presence of physical borders with the United States, a large consumer base, the size of its domestic market and its geography, with access to both the Atlantic and the Pacific oceans. Indeed, the larger the domestic market, the higher the chance that exporting firms can source intermediate inputs from home rather than seeking them from abroad. Similarly, the short distance to potential markets is expected to diminish trade costs and therefore increase the likelihood of trade linkages.

In the case of Mexico, the positive border and NAFTA effects with the United States are most probably higher than the costs linked with distance, e.g. some Asian suppliers are using Mexico as an entrance point to the North American markets. Manufacturing firms that need to minimise response times tend to favour Mexico as a production site when they seek to produce for the North American market. Door-to-door time for products sourced from China's east coast and continuing into the interior of the United States average three to four weeks via the West Coast of the United States and four to six weeks via the East Coast. In contrast, door-to-door time is less than a week for products sourced from Mexico. This advantage in delivery is critical for manufacturing products for which demand is volatile or for perishable, bulky and seasonal products for which carrying costs are high. In addition, the cost of shipping is also an advantage for Mexico. Documented prices of freight costs for shipping a container to Pittsburgh indicate that Mexico costs only 57\% the price shipping from Brazil and $49 \%$ that of shipping from China (Boston Consulting Group, 2008, 2014).

\section{Where does Mexico stand?}

Given the proceeding discussion, Mexico is therefore well integrated to GVCs from a backward participation perspective (Figure 2, Panel A). Thus, the share of foreign value added in Mexico's gross exports is important. However, Mexico remains below peer countries regarding its forward participation to GVCs (Figure 2, Panel B), which means that the share of Mexican value added embodied in foreign countries' exports is low. Mexico's backward and forward participation are skewed towards NAFTA, as anticipated (Figure 2, Panels C and E). Mexico's backward participation is concentrated in medium-high to high technology industries, while its forward participation is concentrated in mining (Figure 2, Panels D and F). The services sector is an area where Mexico's integration is lagging behind peer countries. 
Figure 2 Mexico's backward and forward participation in GVCs, 2011

\section{A. Backward participation index}

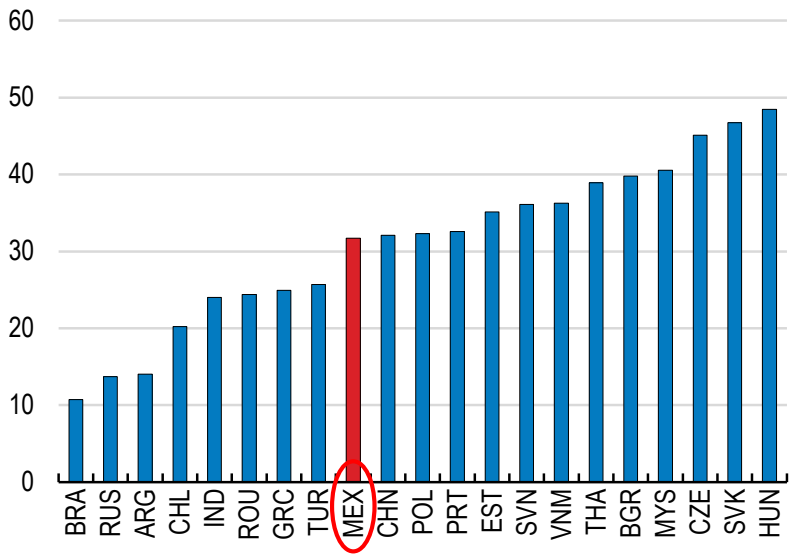

C. Backward participation by origin region

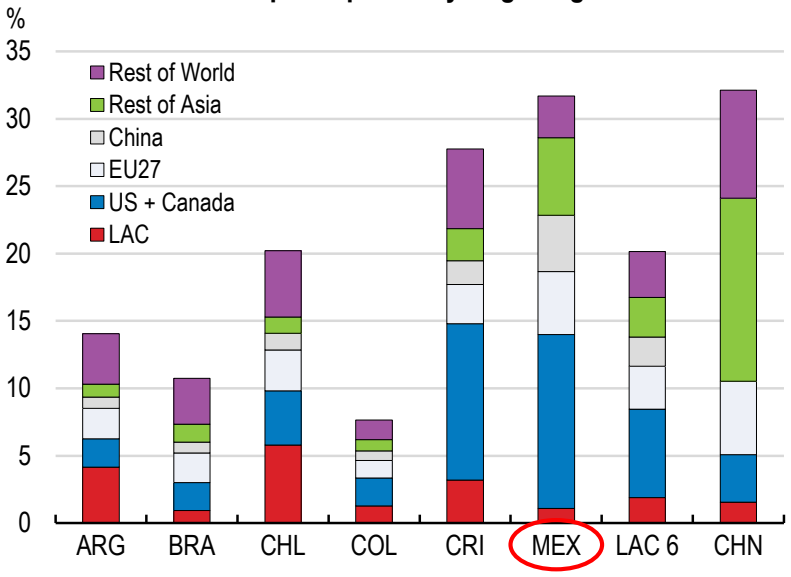

E. Forward participation by destination region

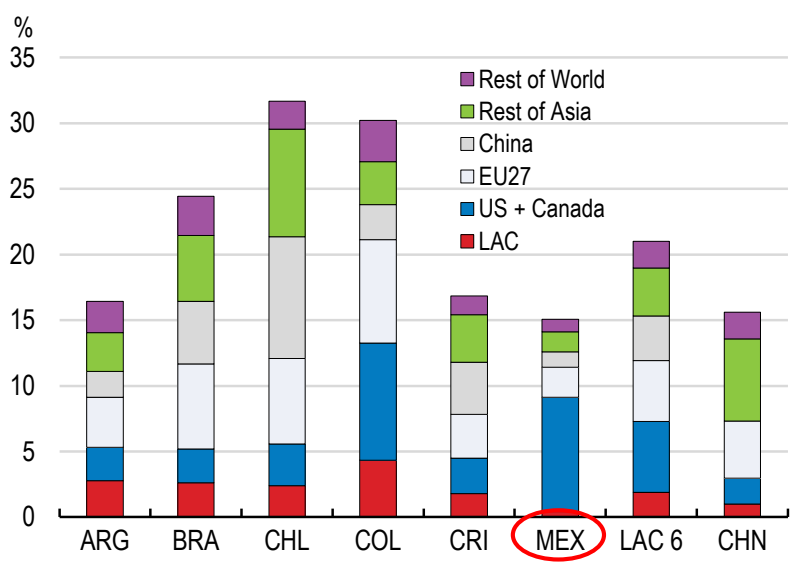

\section{B. Forward participation index}

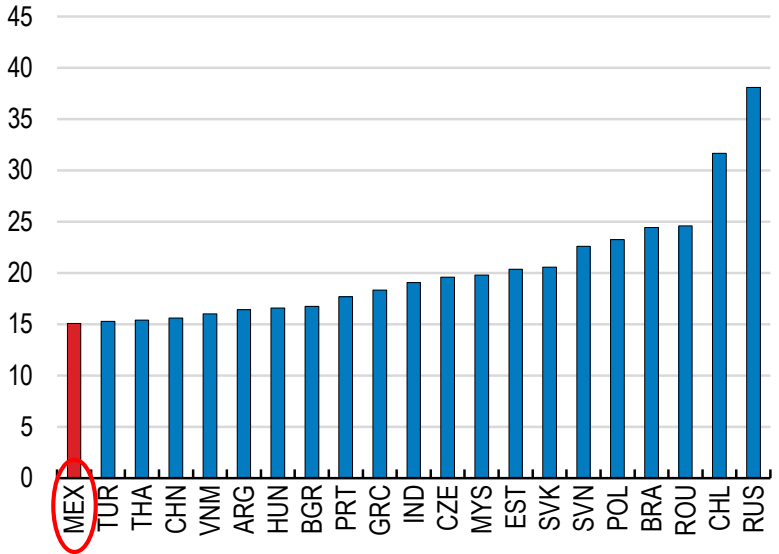

\section{Backward participation by broad sector} composition

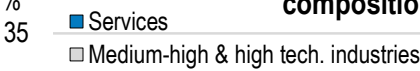
$\square$ Low \& medium-low tech. industries $\square$ Mining

a Agriculture

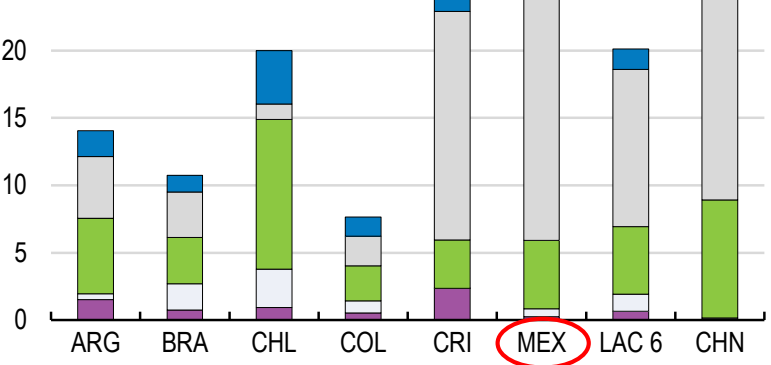

F. Forward participation by broad sector composition

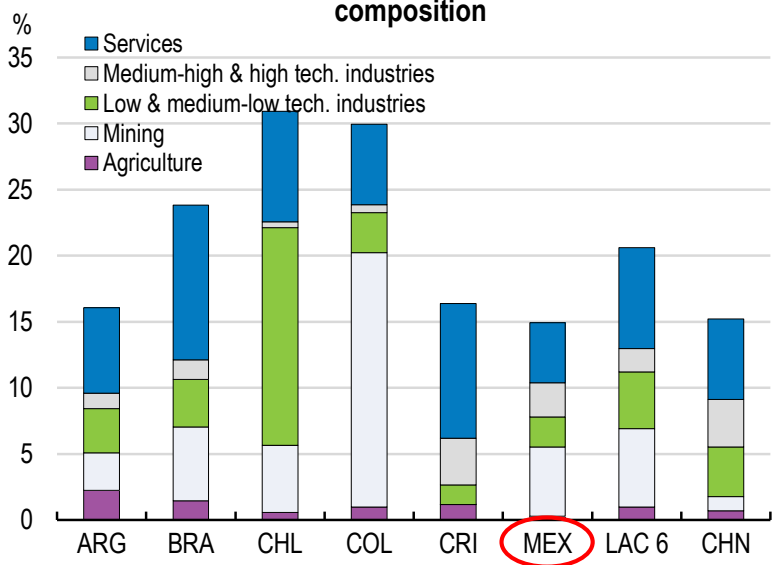

Note: The backward participation index is defined as the share of foreign value added in a country's gross exports. Forward participation is defined as the share of domestic value added embodied in foreign countries' exports. For comparability reasons, most countries included are non-OECD peer countries, such as Brazil, Argentina, Indonesia, Romania, Vietnam, among others.

Source: OECD-WTO Trade in Value Added database. 
In a recent paper, Cadestin et al. (in OECD, 2016a) estimate the determinants of GVC backward participation for Latin American countries for which data on the OECD-WTO Trade in Value Added (TiVA) database is available: i.e., Argentina, Chile, Costa Rica, and Mexico. The determinants of participation are market size, level of development, industrial structure and geographical location, policy determinants such as low import tariffs, both at home and faced in export markets, engagement in preferential trade agreements (PTAs) and openness to inward FDI. Their findings suggest that Mexico's backward integration is high and over-performing against the model (Figure 3). Non-policy determinants are high, and can be explained by Mexico's proximity with the United States. They also find that trade policy plays an important role for Mexico. Finally, their results highlight that FDI openness is not a significant contributor for Mexico, compared to the rest of the sample. Ultimately, the role of policy determinants is most likely underestimated since regression analysis can only take into account the temporal effect of policy while a lot of the structural variables are affected by previous policies. Using a different model, another OECD study (OECD, 2016a) corroborates the finding that Mexico is well integrated from a backward perspective. The determinants in their model are: distance to activity, population, GDP per capita, the share of manufacturing in value added, and the share of natural capital. They also found that Mexico's forward integration is below its expected value.

Figure 3 Backward GVC participation ratio: relative contribution of policy and non-policy factors

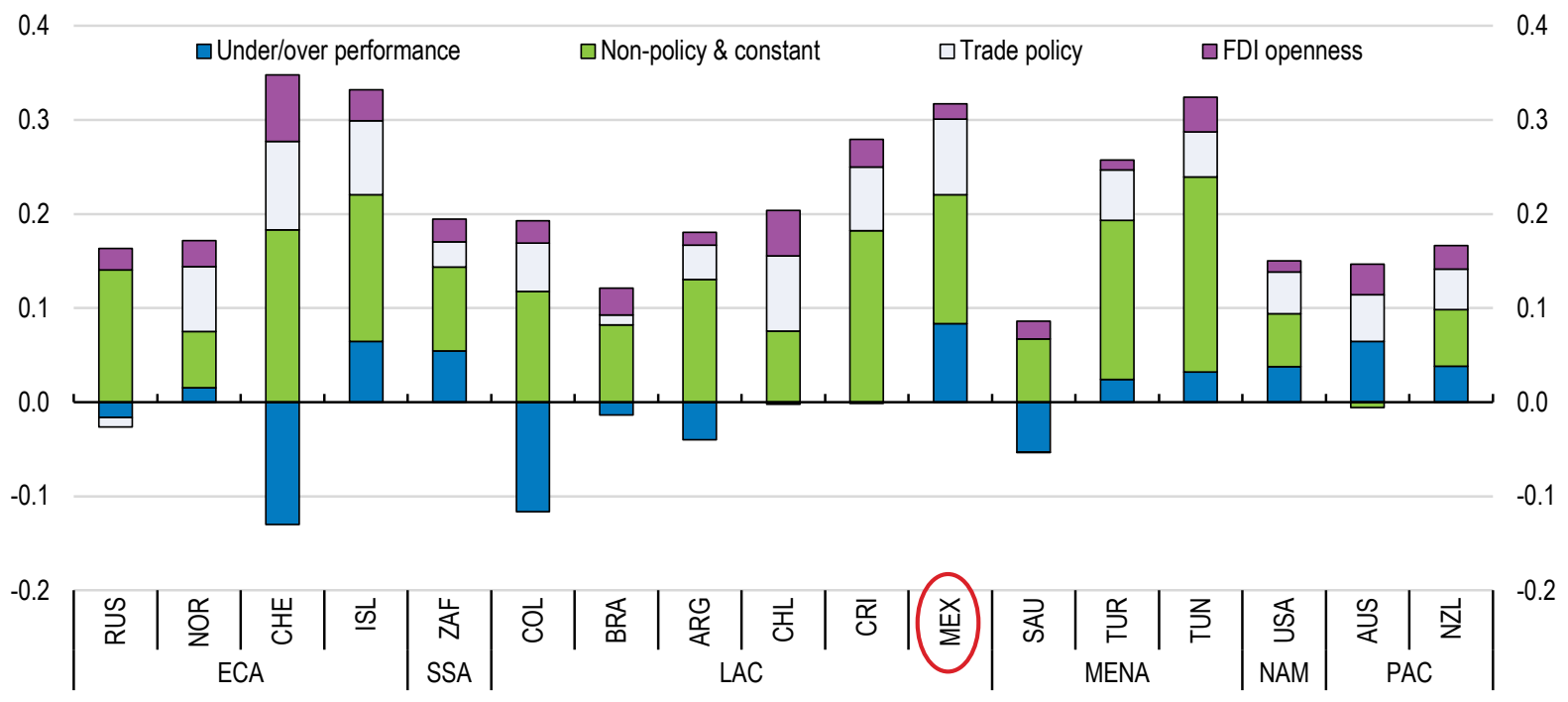

Source: Cadestin et al. (2016)

In another paper, Kowalski et al. (OECD, 2015a) quantify the importance of some other GVC participation determinants across a larger number of developed and developing economies found that trade facilitation and logistics performance, quality of infrastructure and of institutions, intellectual property protection and quality of electricity supply are particularly important (Figure 4). 
ECO/WKP(2017)8

Figure 4 The impact on GVC integration of other policies

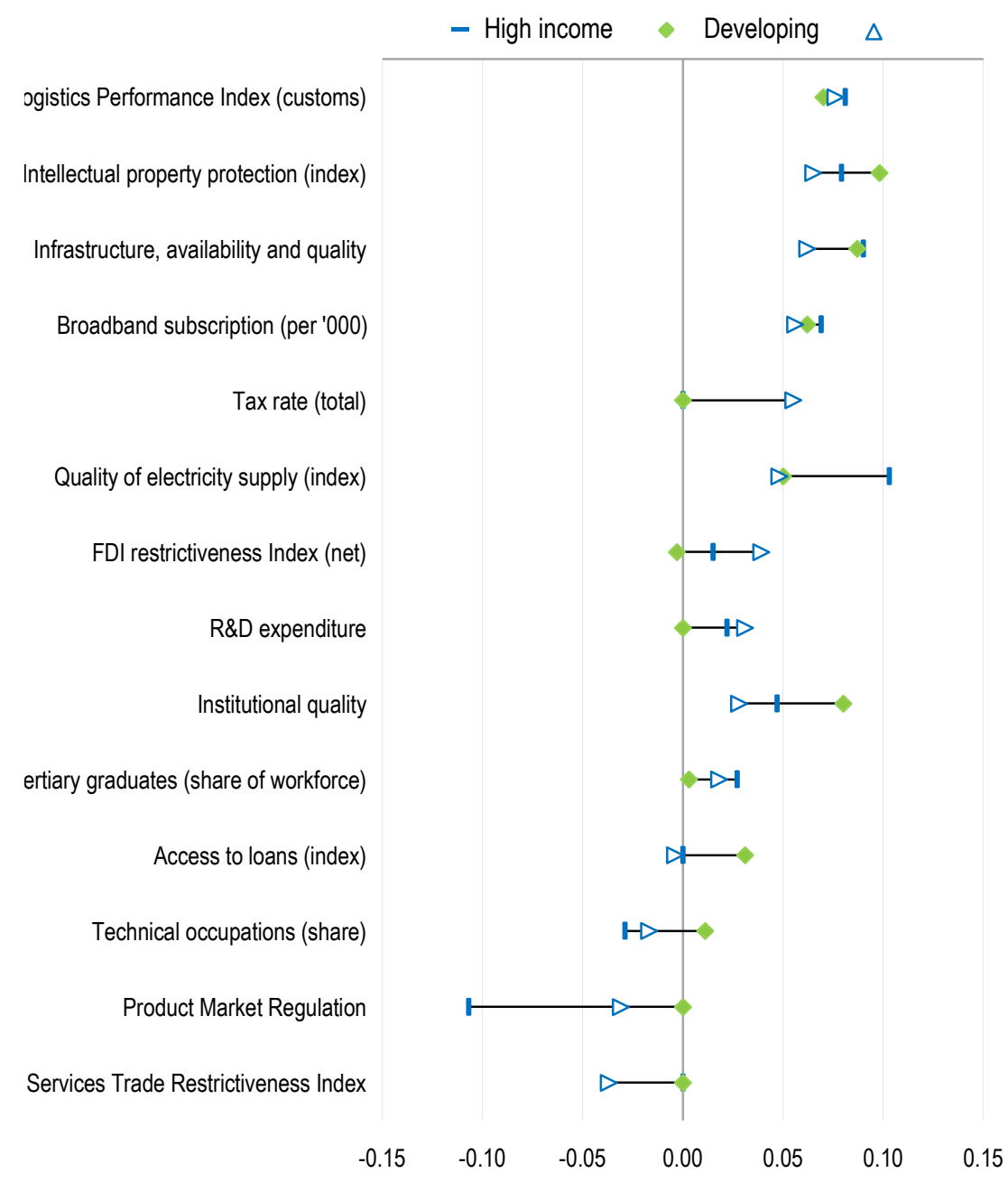

Source: Kowalski et al. (OECD, 2015a).

Since the inception of NAFTA in the mid-1990s, Mexico became a prime supplier of intermediate goods and assembler for the US manufacturing sector. Its integration into GVCs has therefore been mostly through its integration to the US business cycle. The relative stability of the backward participation over time reflects the relatively mature value chains in the NAFTA region (Figure 5, Panel A; OECD, 2015b). The export orientation of Mexico's manufacturers, while low, has steadily increased over the last two decades. This relative low score in forward participation could also be due to the fact that Mexico is increasingly becoming a supplier of final goods, including business services (Figure 5, Panel B). The decline in the share of intermediate goods in trade over recent years could also be the result of slower global growth; however, Mexican manufacturing exports to the United States gained significant market share since the great recession, partly due to a more competitive exchange rate (Panels C and D). Another explanation is that the export of intermediate goods to the United States are increasingly used in US exports and thus explain the slight increase in forward participation over time (see Panel A). 
Figure 5 Mexico's participation in GVCs, share of intermediates in total trade of manufactured goods and export penetration into the US economy

A. Backward and forward participation over time

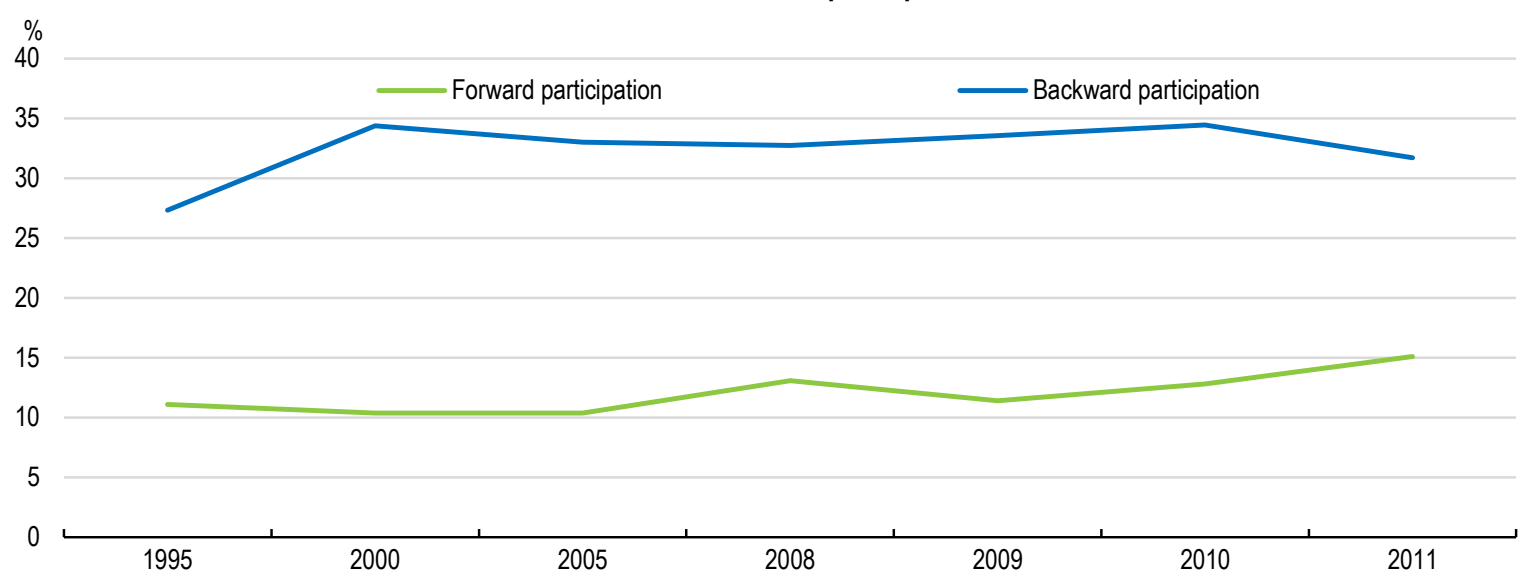

B. Share of intermediate goods in total trade

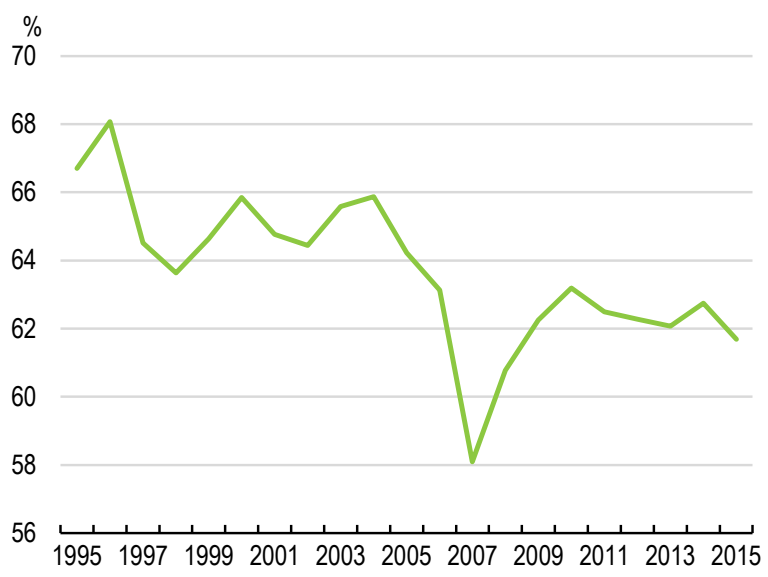

C. Share of Mexico in US non-oil imports

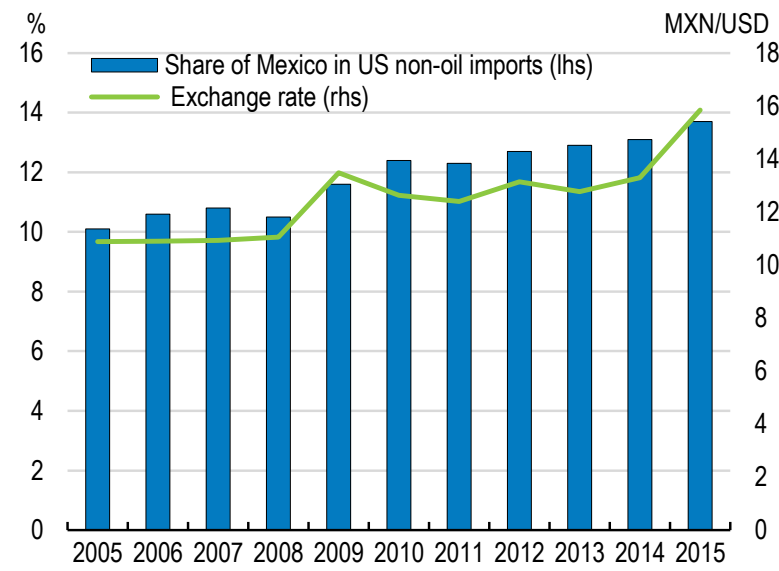

Note: The backward participation index is defined as the share of foreign value added in a country's gross exports. Forward participation is defined as the share of domestic value added embodied in foreign countries' exports.

Source: OECD-WTO Trade in Value Added database, OECD STAN, Banxico and US Dept. of Commerce.

Recent data confirms a decreasing share of Mexico's backward participation to GVCs, with some specific sectors, such as the auto sector - which is typically very import/intermediate intensive - leading the way (Box 1 and Figure 6, Panel A). ${ }^{2}$ The national statistical agency (INEGI) recently released the 2012 Input/Output table, which allows capturing the most recent backward linkage, but does not permit getting an updated measure of forward linkage since it would require Mexico's trade partners' updated Input/Output tables, too. Nevertheless, such increases in domestic value in exports and the fact that Mexico is now more engaged in trade in final goods and high value added products could suggest that some sectors are climbing up the GVCs and the cumulative process of knowledge diffusion may be at play (Figure 6, Panel B). Data from OECD TiVA suggests that the share of domestic value added in exports of final goods has been constant in recent years but the share of domestic value added in exports of intermediate goods has increased.

\footnotetext{
${ }^{2}$ The latest TiVA data for the years 2008 onwards are based on Mexico 2008 Input/Output table. The national statistical agency (INEGI) recently released the 2012 Input/Output table which we are using. While it allows us to capture the most recent backward linkages, we are not able to get an update measure of forward linkages because it would require Mexico's trade partners' updated Input/Output tables too.
} 
Figure 6 Mexico's exports are evolving
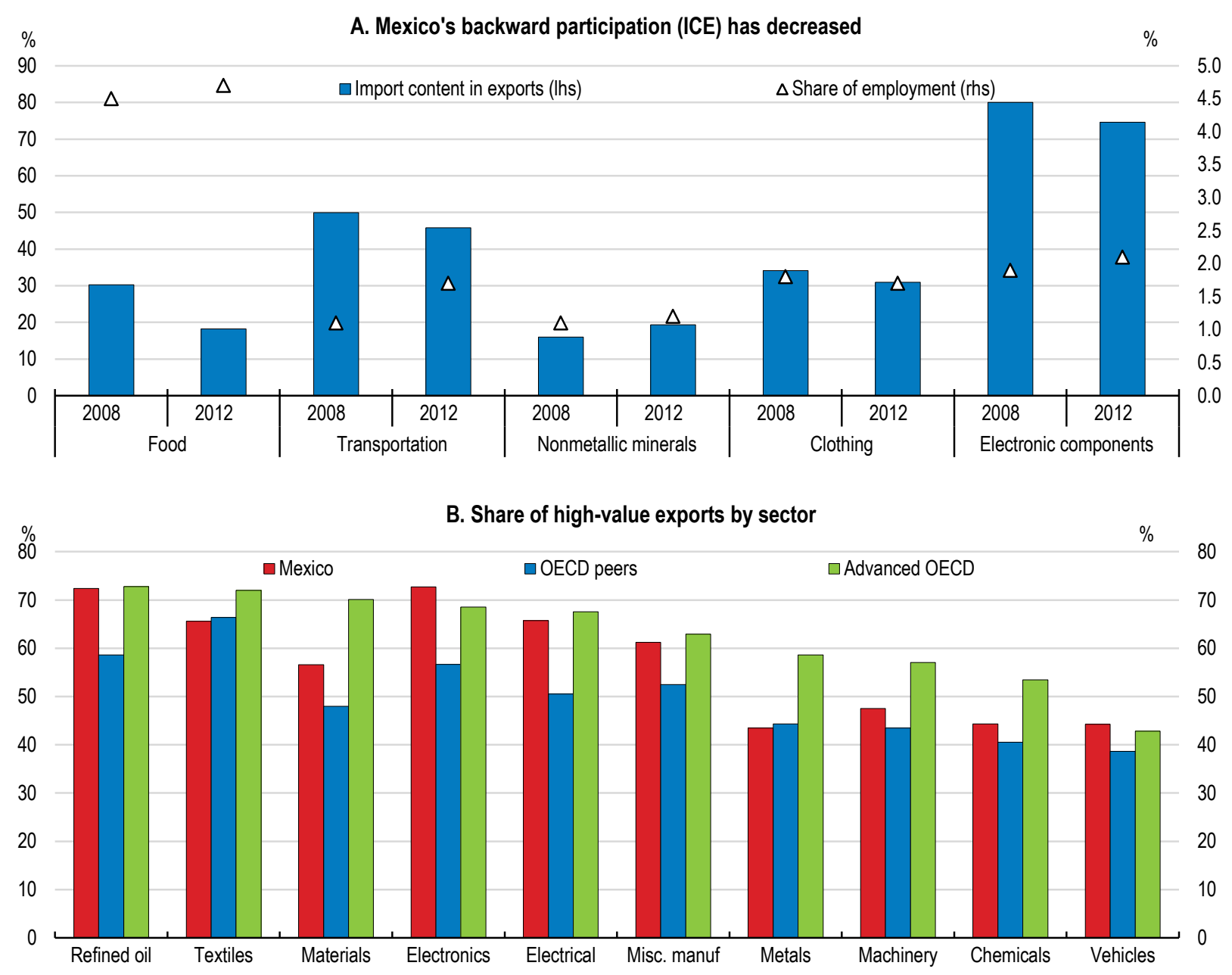

Note: An export is considered of high value when its price exceeds the world's average price by at least $15 \%$.

Source: OECD analysis of INEGI Input/Output tables, CEPII and OECD trade data 


\section{Box 1. Mexico's car industry: A success story}

The Mexican auto sector has grown at impressive rates since the Great Recession and is expected to continue its growth going forward (Figure 7). With favourable labour costs and terms of trade, Mexico has attracted significant foreign direct investment and recently became the United States' prime auto producer, before Canada. Over the last decade, Mexico went from the 20th to the 7th largest worldwide producer of cars between 2005 and 2015, multiplying its total production by about 6 (OIA, 2016). Mexico is also the largest producer of cars in Latin America, and the World 4th largest automobile exporter (PROMEXICO, 2016) (Figure 8, Panel A).

\section{Figure 7 Light vehicles production and installed capacity}

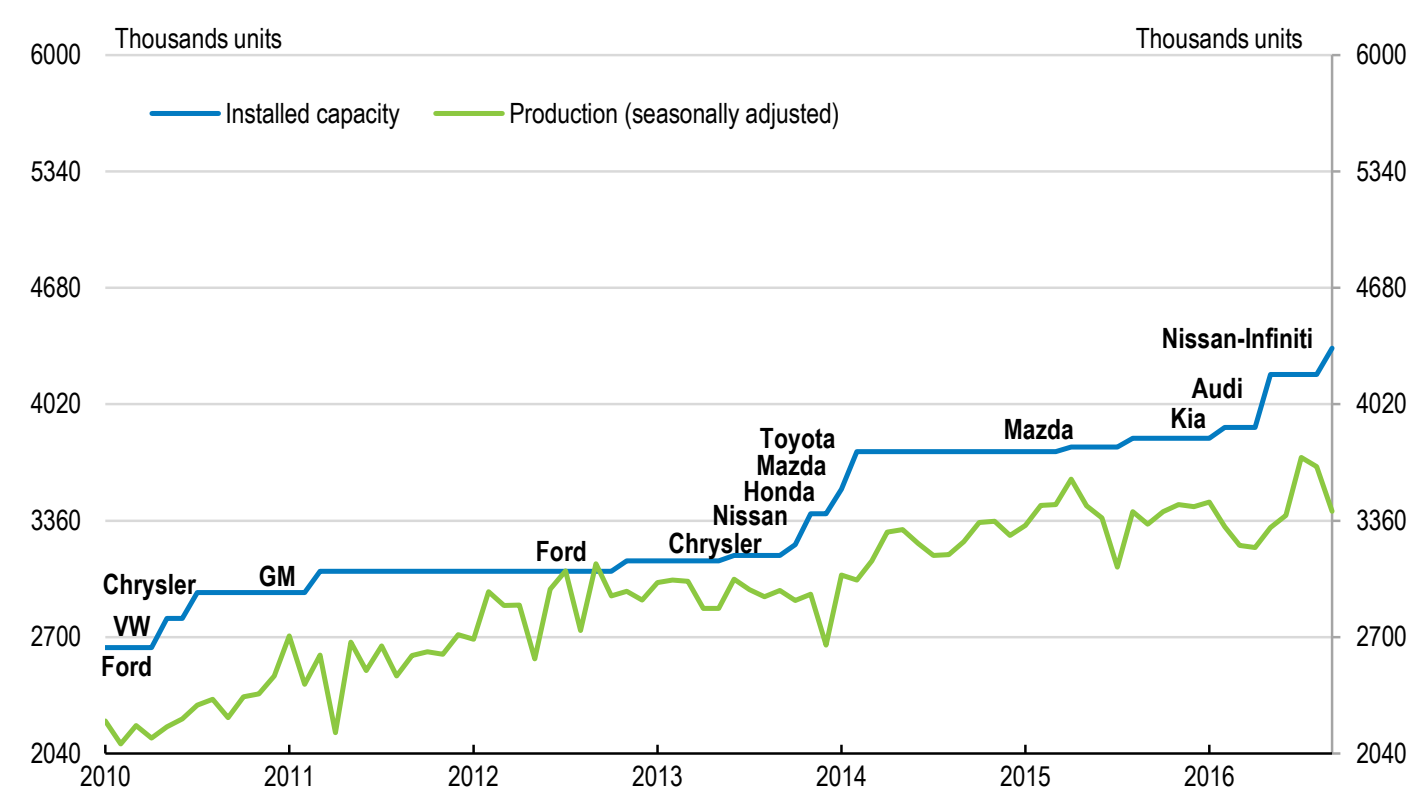

Note: Installed Capacity estimation based on press releases of assemblers and news. Seasonally adjusted data.

Source: Banco de México using data from AMIA.

Mexico's auto sector has benefited from large cumulative foreign direct investments over the last two decades that have allowed the sector to climb up the value chain. First, Mexico is not only producing more cars, but it is producing cars with higher value added, as proxied by the increase amount of luxury cars produced in Mexico (Figure 8, Panel B). In addition, car factories are increasingly moving from assembly to test and design centres (AMIA, 2016). Another indicator that the Mexican auto sector is climbing up the value chain is the diminution of imported content in auto exports (ICE, the ICE is as a good measure of international 'backward linkages' in analyses of global value chains). The ICE in the auto industry has decreased from about $50 \%$ in 2008 to $46 \%$ in 2012, and is estimated (see Box 2 ) to have decreased to about $43 \%$ in 2014.

Recent studies show that the successful development of the auto industry in Mexico is characterised by high geographic concentration, via the formation of clusters, far superior in this industry than in the other manufacturing industries (Chavez and Garcia Loredo, 2014). These results indicate that one of the factors driving growth in this sector is the presence of agglomeration economies. Those results have macroeconomic implications at the State level and the development of the auto exports business has benefited those States with higher share of auto exports (See Figure 8, Panel C).

(Box continued....) 
Box 1. Mexico's car industry: A success story (Box continued)

Figure 8 Auto sector performance
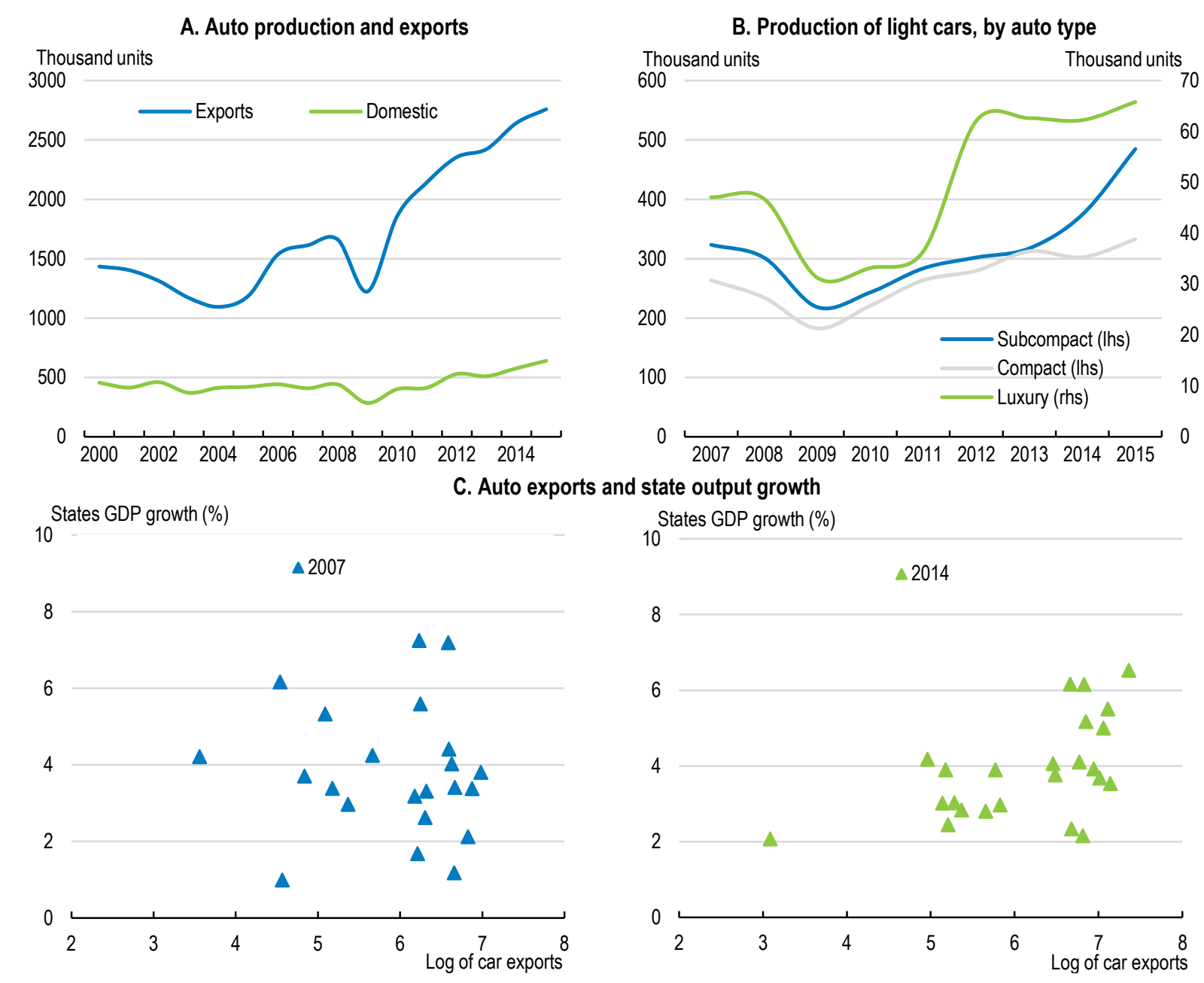

States GDP growth (\%)

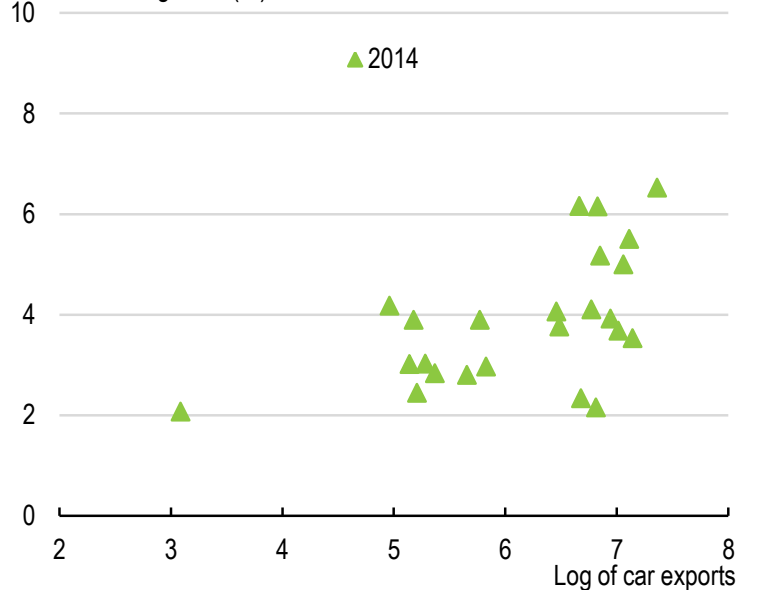

Source: OECD calculations using data from AMIA, INEGI, and Banco of Mexico

Lower import content in exports, or higher domestic content in exports does not per se translate into value added created in Mexico. Trading more final products, no matter where the value added comes from, can increase Mexico's backward participation to GVCs, but trading final products could also limit forward participation in GVCs. An exercise forecasting Mexico's recent backward participation trend shows that while it is projected to have increased for the whole economy, it is expected to have decreased for the manufacturing sector (Box 2). Yet, the benefits linked to forward participation are as important as are the ones from backward participation. Gauging where Mexico's integration stands compared to peer OECD countries at the sectoral level reveals interesting patterns. Mexico's low forward participation is indeed due to fact that the country's exports are mostly final goods directed to the United States (Figure 9, Panel A). Yet, a good counter-example is again the auto sector: the auto sector has a low forward participation but the sector is highly integrated, supporting the evidence of climbing up the supply chain. Mexico's backward participation is more homogeneous, in particular in the manufacturing sectors (Figure 9, Panel B). 
Figure 9 Mexico's backward and forward participation to GVCs in selected sectors vs peer OECD countries
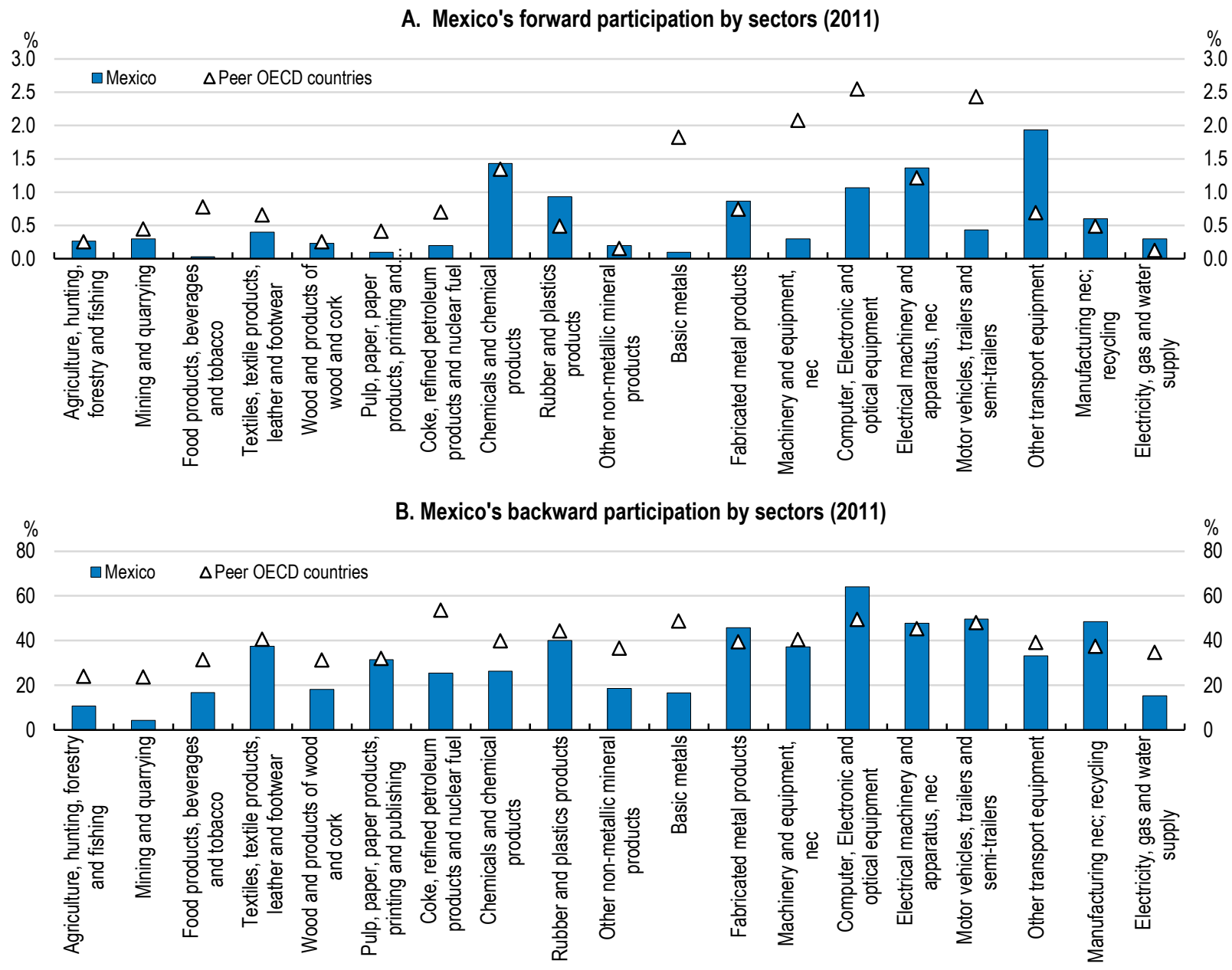

Note: Panel A: Forward participation to GVCs is defined as the domestic value added embodied in foreign exports as share of gross exports. Panel B: Backward participation to GVCs is defined here as the foreign VA embodied in exports, as \% of total gross exports. Peer OECD countries are: CHL, CZE, EST, HUN, KOR, LVA, SVK, SVN, TUR.

Source: OECD calculations with OECD-WTO TiVA Database. 


\section{Box 2. Projecting Mexico's backward integration to GVCs in 2014}

In order to gauge the evolution of Mexico's backward participation over more recent years, the latest trade and FDI data are used to forecast Mexico's backward participation up to 2014. An econometric approach to project the industries' backward participation (import content in exports, ICE) levels up to 2014 using (I) the 2012 ICEs from the 2012 input/output table and (ii) regressing the 2003, 2008 and 2012 ICEs to determinants such as industries' imports, industries' FDI, and exchange rate fluctuation to control for price movements. Our regression analysis is based on a panel of ICE levels per industry for the years 2003, 2008 and 2012, using random effects. The estimated equation is:

$$
I C E_{i t}=c+F D I_{i t}+M_{i t}+E X R_{t}+\varepsilon_{i t}
$$

where $I C E_{i t}$ represents the import content in exports for each industry $i$ at time $t, F D I_{i t}$ represents the cumulated flows of foreign direct investment in the industry $i$ at time $t$ in log, $M_{i t}$ the cumulated imports in the industry $i$ at time $t$ in log, $E X R_{t}$ the change of the effective exchange rate over the period, and $\varepsilon$ the residuals. The results indicate that the fit is good and the determinants are significant (Table 1). In a recent paper, OECD (2016) uses a different methodology to forecast backward GVC integration. Their structural GVC indicator captures the slowdown in 2012 well, but predicts an increase for 2014. Our analysis suggests that while ICE is likely to have increased for the whole economy by 2014 , it is expected to have decreased for the manufacturing sector (Figure 10).

\section{Table 1. Estimation results of ICE model by industries}

\begin{tabular}{|c|c|}
\hline & Dependent variable: ICE \\
\hline FDI & $0.007^{*}$ \\
\hline M & $0.029^{* * *}$ \\
\hline EXR & $-0.009^{\star *}$ \\
\hline \multicolumn{2}{|l|}{ R-square } \\
\hline Overall & 0.338 \\
\hline Within & 0.237 \\
\hline Between & 0.328 \\
\hline Observations & 110 \\
\hline Industries & 39 \\
\hline Wald test & $36.46^{* \star \star}$ \\
\hline$\sigma^{u}$ & 0.127 \\
\hline$\sigma^{e}$ & 0.038 \\
\hline$\rho$ & 0.916 \\
\hline
\end{tabular}

Note: ${ }^{* * *}$ indicates significance at the $1 \%$ level, ${ }^{* *}$ at the $5 \%$, and ${ }^{*}$ at the $10 \%$.

Source: OECD calculations using INEGI and Banxico data.

Figure 10 Projected 2014 backward GVC integration in manufacturing industries (ICE)

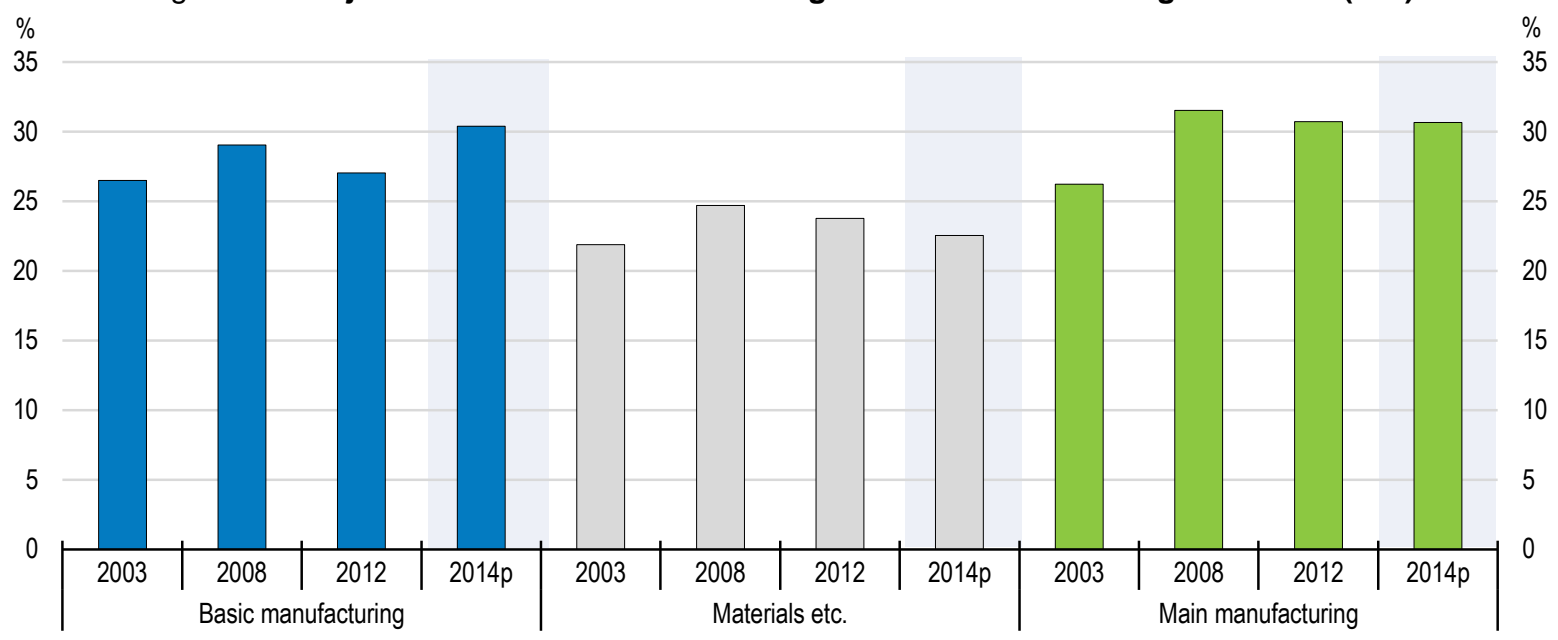

Source: OECD calculations using INEGI and Banco de México data. 


\section{Where does Mexico have a comparative advantage?}

The complexity of a country is a broad measure of the set of capabilities available in a country. Technically, it is a projection of the matrix connecting countries to the products they export. Since the complexity measure considers information about the diversity of countries and the ubiquity of products, it is able to produce a measure of economic complexity containing information about both the diversity of a country's exports and their sophistication. For example, Japan or Germany, with high complexity measures, export many goods that are of low ubiquity and that are produced by highly diversified countries, indicating that these are diverse and sophisticated economies. Countries with low complexity measures export only a few products, which are of relatively high ubiquity and which are exported by countries that are not necessarily very diversified, indicating that these are countries that have little diversity and that the products that they export are not very sophisticated (see Hidalgo and Hausmann, 2009).

Complexity measures have been found to be good predictive of future growth and predictive of the complexity of a country's future exports, making a strong empirical case that the level of development is indeed associated to the complexity of a country's economy (Hidalgo and Hausmann, 2009). Countries' value chain activity is also linked to growing sophistication and diversification of exports as is the use of more sophisticated inputs (OECD, 2015; Taglioni and Winkler, 2015). Recent studies show that Mexico has the potential to further integrate and climb up GVCs since its aggregate measure of complexity is relatively high (Hidalgo and Hausmann, 2009). The National Productivity Committee make economic complexity measures available by municipality and industry, and authorities are using these measures to support their policy framework. Cross checking those measures by industries with GVC indicators yield interesting results: sectors' complexity and strategic product value (as measure by the product's complexity potential) are positively related to backward participation to GVCs in Mexico (Figure 11).

Figure 11 Sectorial complexity measures vs backward participation in GVCs (ICE)
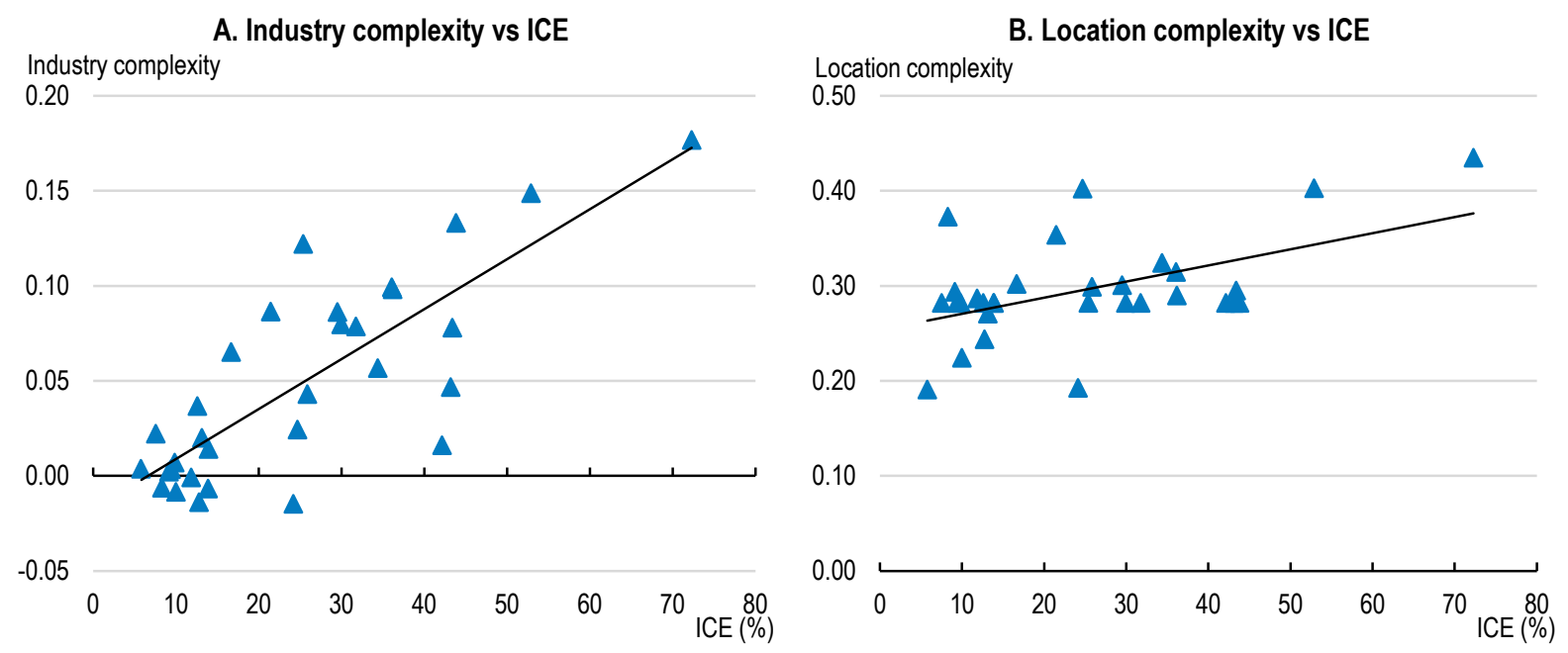

Note: Data corresponds to 3-digit industry-level observations from years 2003 to 2014.

Source: OECD calculations with INEGI and GOB.MX data.

While the link between complexity and backward GVC participation is robust, the relation with labour productivity does not seem to hold (Figure 12, Panel A). In addition, the relation between labour productivity and the revealed comparative advantage measure is not significant either, indicating that Mexico is not fully exploiting the potential gains from its comparative advantages (Figure 12, Panel B). 
The revealed comparative advantage (RCA) is a good indicator of potential for export growth. It is the proportion of the country's exports that are of the class under consideration $\left(E_{i j} / E_{i t}\right)$ divided by the proportion of world exports that are of that class $\left(E_{n j} / E_{n t}\right)$. A comparative advantage is "revealed" if $\mathrm{RCA}>1$. If RCA is less than unity, the country is said to have a comparative disadvantage in the commodity or industry.

Figure 12 Backward GVC participation and labour productivity vs revealed comparative advantage (RCA)

\section{A. Productivity vs ICE}

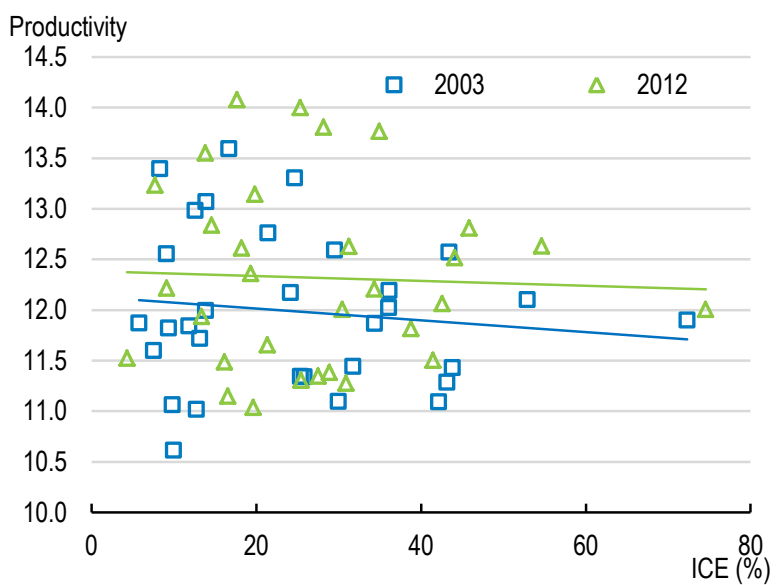

B. RCA vs ICE

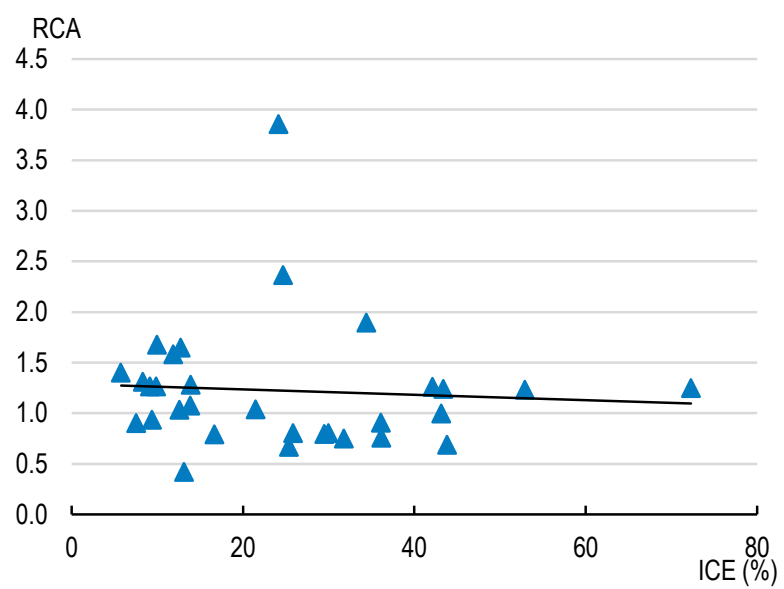

Note: Data corresponds to 3-digit industry-level observations from years 2003 to 2014.

Source: OECD calculations using INEGI and GOB.MX data.

Activities where Mexico has the greatest competitive or comparative advantages are manufacturing goods with a high weight to value ratio, whose quality is more important than their prices, that are specially protected under NAFTA rules and whose production is mainly oriented towards foreign markets. According to Watkins (2007), Mexico has comparative advantages in the following four lines of production; (i) manufacturing production with a high weight to value ratio (the production of cars, flat screens and appliances of large size); (ii) production of firms that implement just-in-time procedures and whose production is subject to frequent changes in design (auto parts); (iii) goods that require strong managerial involvement in order to meet high quality standards (aerospace industry and medical instruments) and; (iv) manufacturing goods where the protection of property rights is important.

\section{How can Mexico further integrate and climb up GVCs?}

This paper refers to climbing up GVCs as an economy's ability to create larger value in GVCs by observing the ratio of domestic value-added embodied in its exports to its actual exports (discussion above and OECD, 2013). Such a focus on value-added corresponds to the concept of "high value-added activity" in the GVC literature, a concept which refers to activities that are better remunerated (have higher margins) and have higher entry barriers because the skills required are difficult to obtain. Therefore, a particularly important driver for upgrading in GVCs is investment in knowledge-based capital (KBC) (OECD, 2013). GVCs encourage productivity growth by accelerating learning and innovation and by broadening and deepening the skill set in a country. The highest level of value creation in a GVC is often found in certain upstream activities, such as new concept development, design, R\&D, or the manufacturing of key parts and components, as well as in certain downstream activities, such as marketing, branding, or customer service. Such activities involve tacit, non-codified knowledge in areas such as design, the creation and management of cutting-edge technology, and complex systems, as well as management or organizational know-how. 
Different types of KBC play a role in GVCs (OECD, 2013): (a) computerised information (software and databases); (b) innovative property ( $R \& D$ and non-R\&D innovative expenditures, including copyrights, designs, and trademarks); and (c) economic competencies (brand equity, firm-specific technological and managerial skills, networks, and organizational structures).

While work on measurement of $\mathrm{KBC}$ has made tremendous progress in recent years, there is still no good measure for Mexico (OECD, 2013). An early proxy was the Knowledge Economy Index (KEI), from the World Bank Institute, representing the overall level of development of a country or region towards the Knowledge Economy. The 2012 KEI puts Mexico at the bottom among OECD countries (Figure 13). ${ }^{3}$ The rest of this section discusses the link between productivity and backward integration with measures of $\mathrm{KBC}$ for Mexico, as proxied by FDI, R\&D, innovation and skills, with a focus at the sector level.

Figure 13 Mexico Knowledge Economy Index (KEI) is the lowest among OECD countries Index from 0 (least knowledge-based) to 10 (most knowledge-based economy)

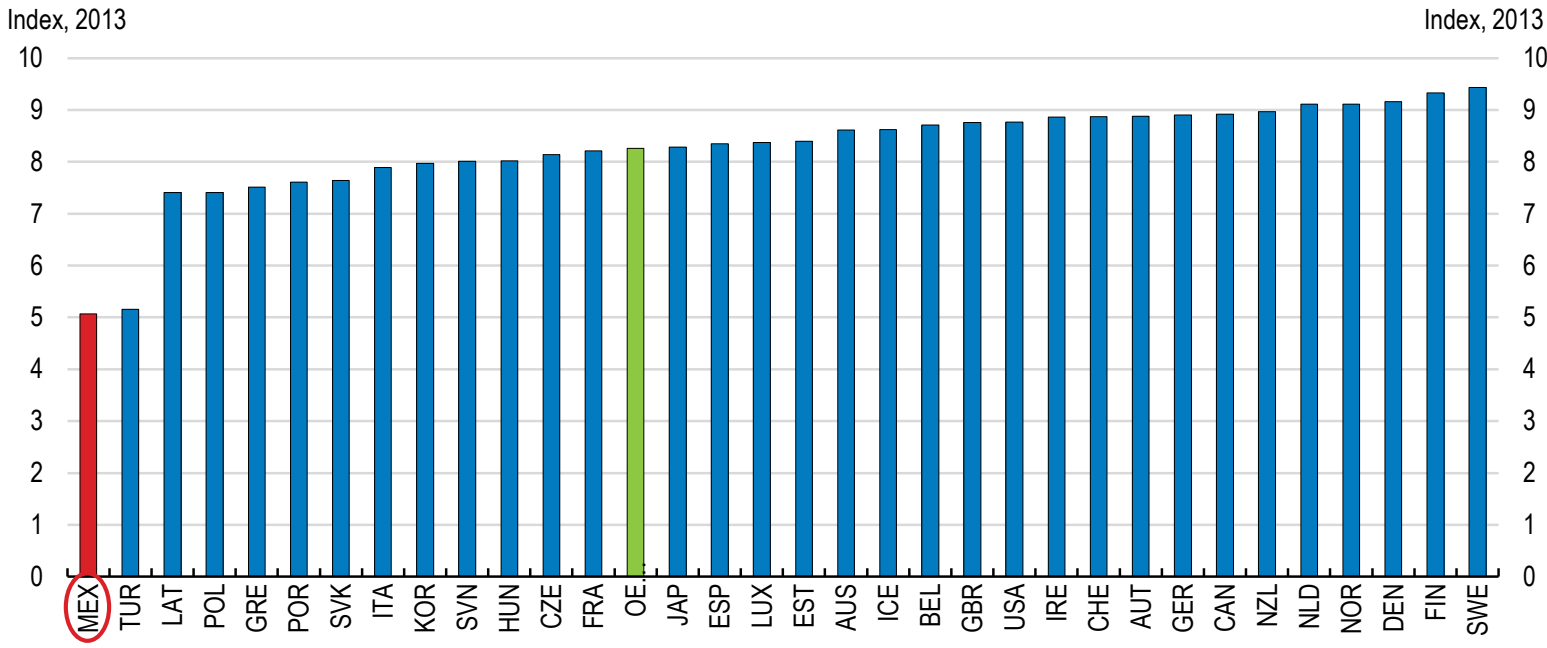

Note: Data not available for Chile and Israel.

Source: World Bank, Knowledge for Development, 2013.

\section{Foreign Direct Investment (FDI)}

Mexico attracts significant FDI flows (Figure 14, Panel A), however its stock of inward FDI remains low compared to peer countries (Figure 14, Panel B).

\footnotetext{
${ }^{3}$ The KEI is calculated based on the average of the normalised scores (on a scale of 0 to 10 relative to other countries in the comparison group; with 10 is the top score for the top performers and 0 the worst for the laggards) of the country or region on all four pillars related to the knowledge economy - economic incentive and institutional regime, education, innovation and ICT. For the purposes of calculating KEI, each pillar is represented by three key variables: The Economic Incentive and Institutional Regime (tariff \& nontariff barriers, regulatory quality, rule of law); Education and Human Resources (adult literacy rate, secondary enrolment, tertiary enrolment); the Innovation System (royalty and license fees payments and receipts, patent applications granted by the US Patent and Trademark Office, scientific and technical journal articles); and Information and Communication Technology (telephones per 1000 people, computers per 1000 people, Internet users per 10000 people). Source: World Bank (2013).
} 


\section{A. FDI inflows}

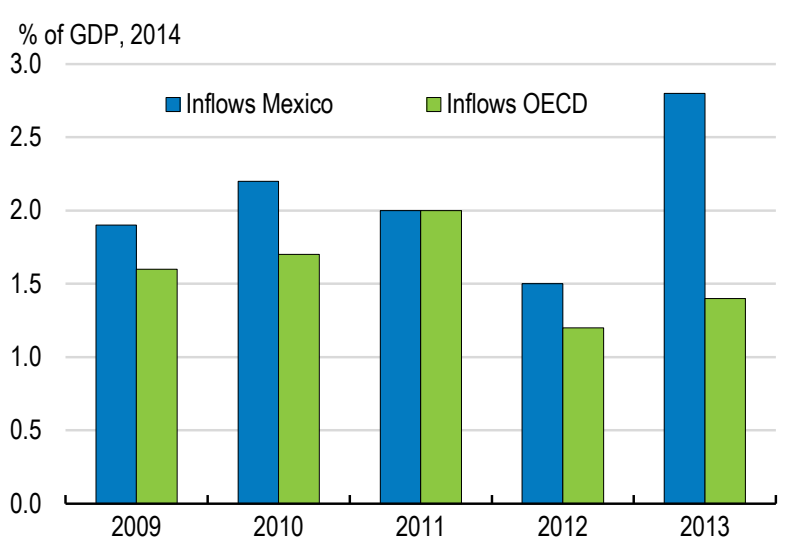

B. FDI inward stocks

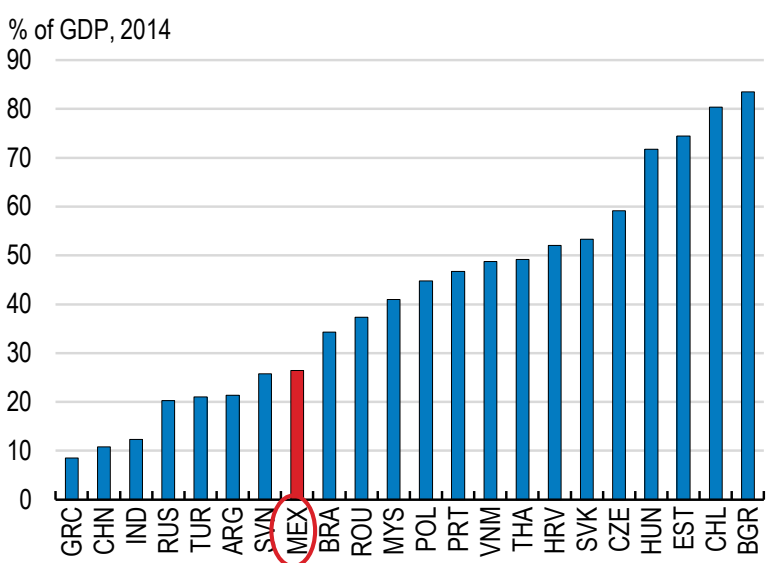

Source: OECD International Direct Investment Statistics.

Integration into GVCs is typically linked to FDI spillovers, which are also, through knowledge diffusion, a determinant of productivity growth. Positive changes in foreign sourcing are associated with positive changes in the per capita domestic value added in exports, which suggests that a greater use of foreign inputs is complementary to a growing per capita domestic value added in exports (OECD, 2015; Taglioni and Winkler, 2015). Javorcik (2008) reports that the presence of multinationals can lead to knowledge spillovers to local firms in the same industry or to local firms in the supplying sectors, which can facilitate product upgrading. However, the spillover effects of FDI inflows are not straightforward to capture and estimation results are mixed, with some studies reporting negative spillovers. For Mexico, the stock of FDI is positively correlated to both import content (ICE) and labour productivity levels at the sector level (Figure 15). Sectors more exposed to FDI are therefore more integrated into GVCs and show higher labour productivity.

Mexico is among the most open large economies in the world, thanks in part to its free-trade policies. Much progress has been achieved to reduce trade barriers, make it easier to do business, and improve regulation. Barriers to foreign investment and services trade have been reduced in key sectors (Figure 16) notably media and telecoms - but a substantial gap remains to OECD best practice in sectors such as in air and road transport (Figure 16, Panels A and B). In particular, sectors that are key determinants of GVC integration have stringent regulation, such as logistics (Figure 16, Panel B). Those barriers could be reduced further in nearly all sectors, through systemic reforms. 
Figure $15 \mathrm{FDI}$, backward integration to GVCs and labour productivity
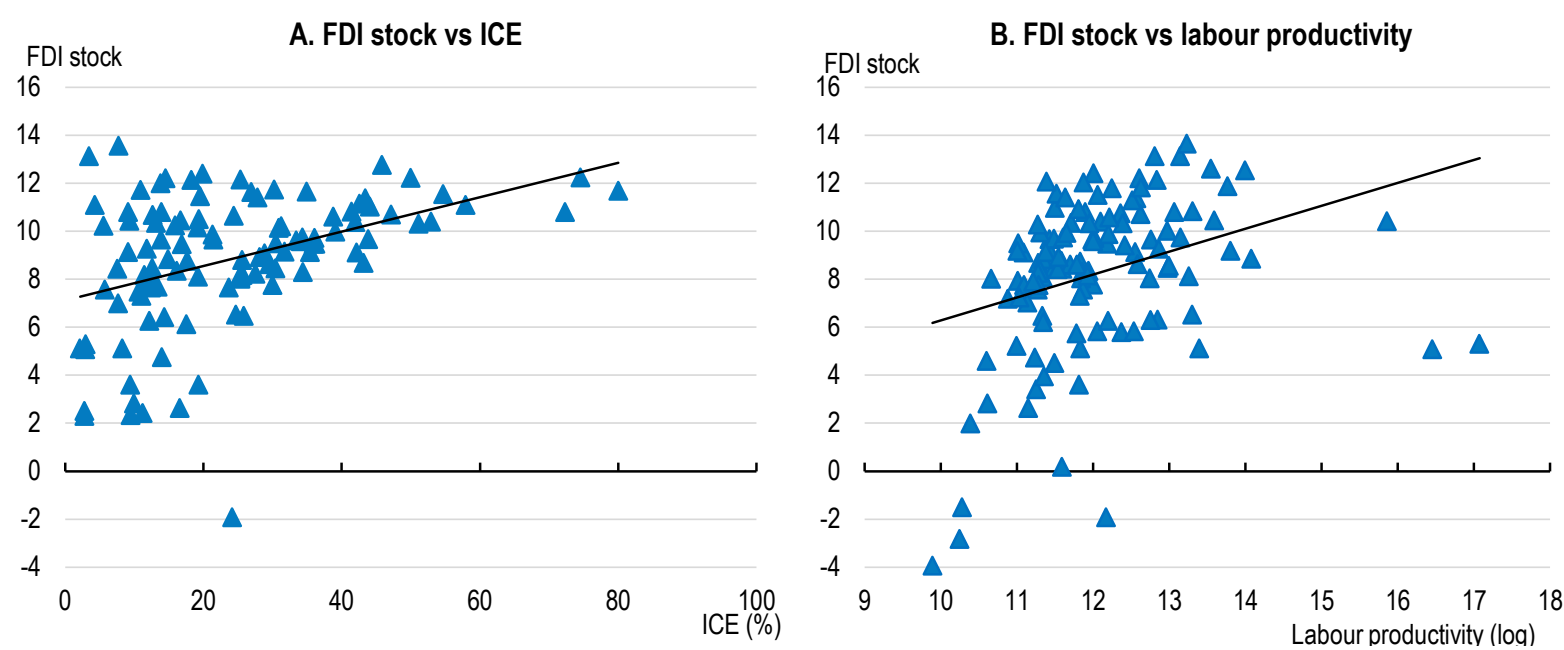

Note: Backward participation to GVCs is proxied by import content in exports (ICE). Labour productivity is defined as the sector's value added per worker, in log. FDI is cumulated FDI over 2008-2014 in current pesos, in log.

Source: OECD calculation with INEGI data.

Figure 16 Foreign investment and service trade barriers remain high in some sectors Indexes from 0 (least restrictive) to 1 (most restrictive)
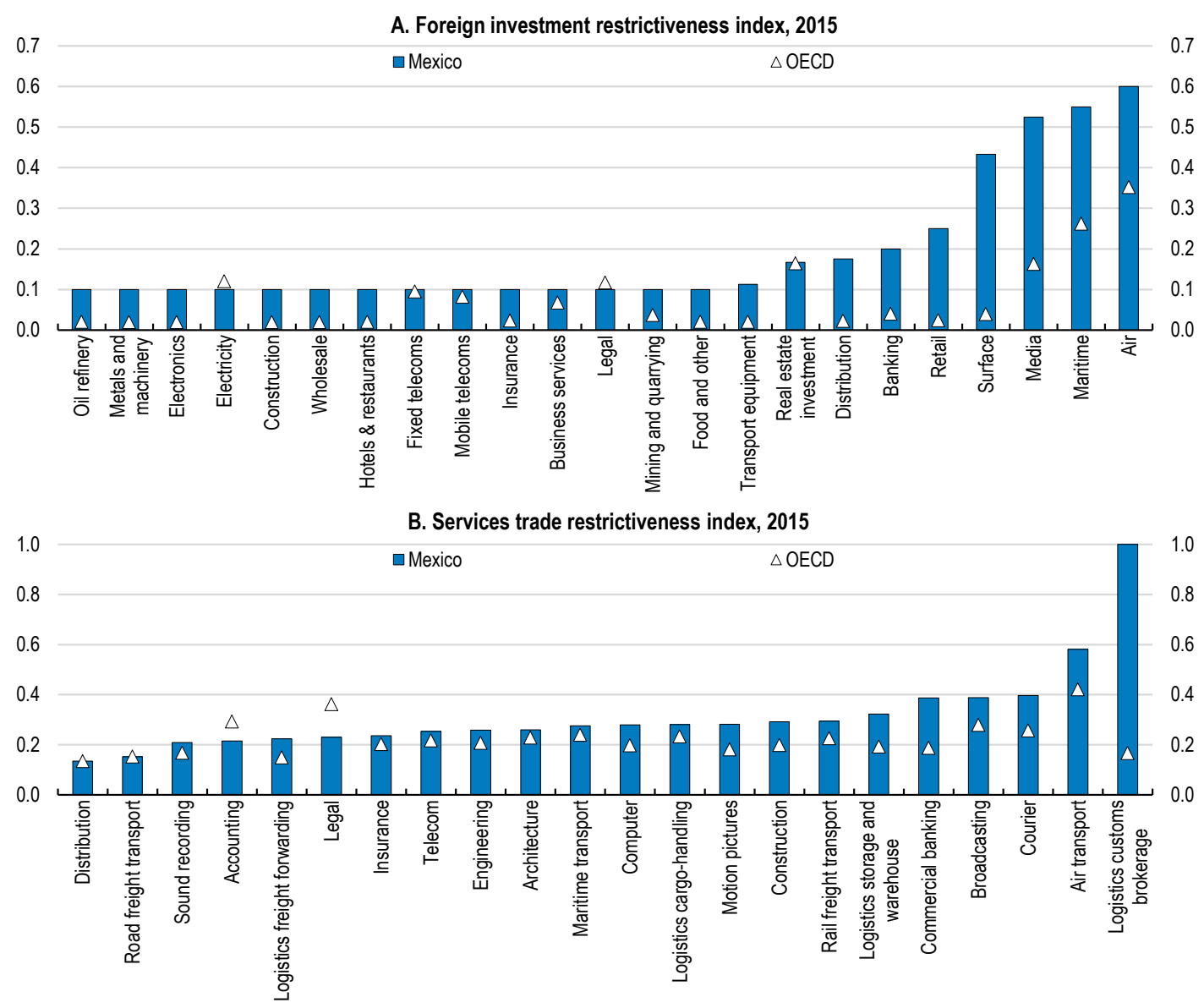

Source: OECD FDI and Services Trade Restrictiveness Databases. 


\section{Research and Development $(R \& D)$ and innovation}

Overall spending in R\&D is relatively low in Mexico. Private sector R\&D investment is well below that of nearly all OECD and BRICS countries (Figure 17, Panel A). Public sector spending is also low, although catching up OECD average (Figure 17, Panel B). Low R\&D spending is partly a result of Mexico's industrial structure, as over one-third of manufacturing R\&D is carried out in low and mediumtechnology sectors. However, obstacles to boosting the country's innovative potential include a weak domestic research and skills base, an underdeveloped knowledge-based start-up environment and institutional challenges. Raising R\&D intensity further is one of the priorities of the current administration, which intends to double R\&D spending from the current $0.54 \%$ of GDP to $1 \%$. A tax credit on R\&D will start in 2017, which will allow participating firms a $30 \%$ tax credit on their R\&D expenditures. However, in order to support the private sector to integrate and climb up GVCs, the government and states need to foster co-operation between public and private research centres, as the tertiary education system supported the formation of students for specific sectors such as aeronautics clusters in the state of Querétaro.

Figure 17 Research and development (R\&D) expenditure
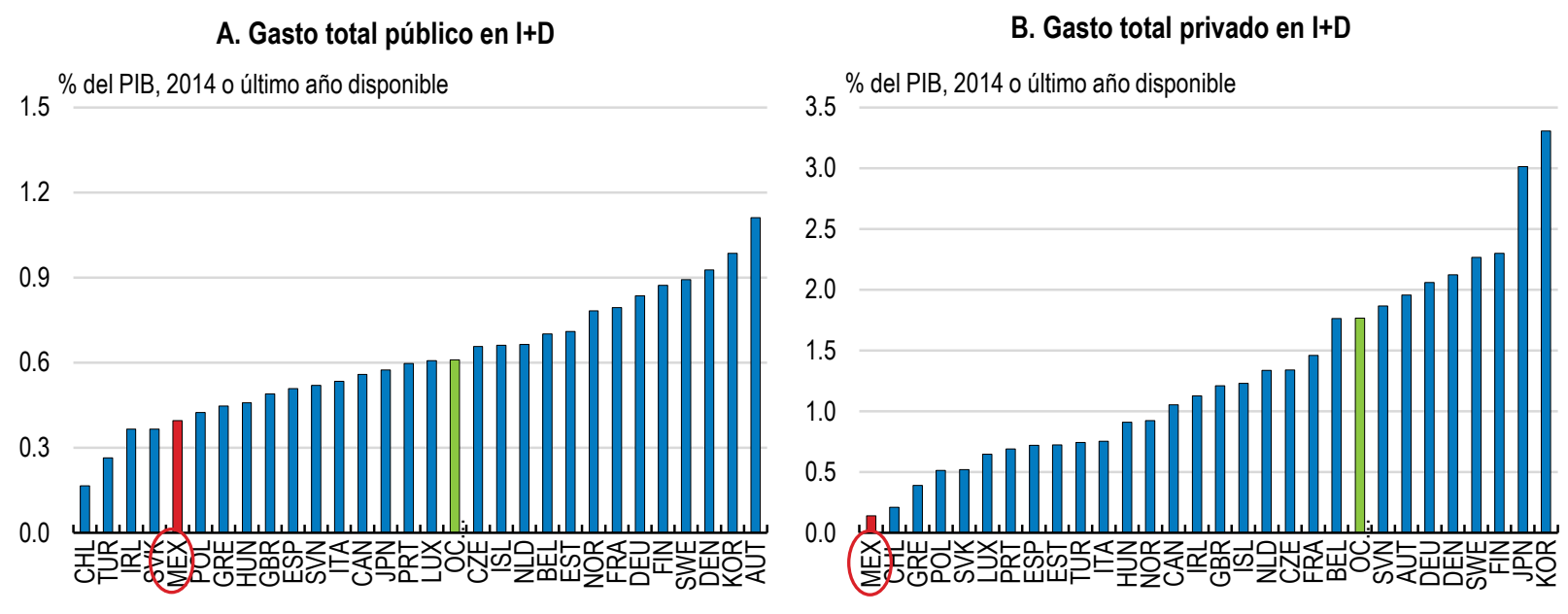

Source: OECD Science, Technology and Industry Scoreboard (2015).

Productivity growth relies on the diffusion of innovation from firms at the global frontier to other firms, which is facilitated by trade openness and participation in GVCs (OECD, 2015). Knowledge is also transmitted through spending on R\&D. Innovation is seen by firms as one important requirement for their successful participation in global value chains (OECD, 2008). Process and organisational innovation increases firm productivity by reducing production costs and allowing firms to achieve the minimum level of efficiency required to cover fixed exporting costs. Product innovation creates learning-by-doing effects and helps firms offer new and upgraded products, while marketing innovation and innovative branding strategies allow firms to differentiate their products from those of their competitors and gain market share in GVCs. Innovative firms are more likely to participate in international markets than non-innovative firms (OECD , 2015). Industries that source intermediates that embody a higher R\&D knowledge content tend to have higher productivity (Nishioka and Ripoll, 2012), suggesting embodied R\&D can be a form of technology transfer to local firms. In the case of Mexico, the relation between spending in $R \& D$ at the industry level is positively correlated to backward integration (ICE) and productivity levels (Figure 18, Panel A). Typically, industries based on information and communications technologies (ICTs) are more productive and tend to be more integrated to GVCs due to their innovation content (OECD, 2015). In Mexico, more innovative industries, i.e. industries with larger technical assets, are not found to be more integrated into GVCs but the correlation with labour productivity is positive (Figure 18, Panel B). 
Figure 18 Sectors spending more in R\&D are more integrated in GVCs and enjoy higher labour productivity

\section{A. Productivity, backward GVC integration and R\&D}

R\&D vs ICE

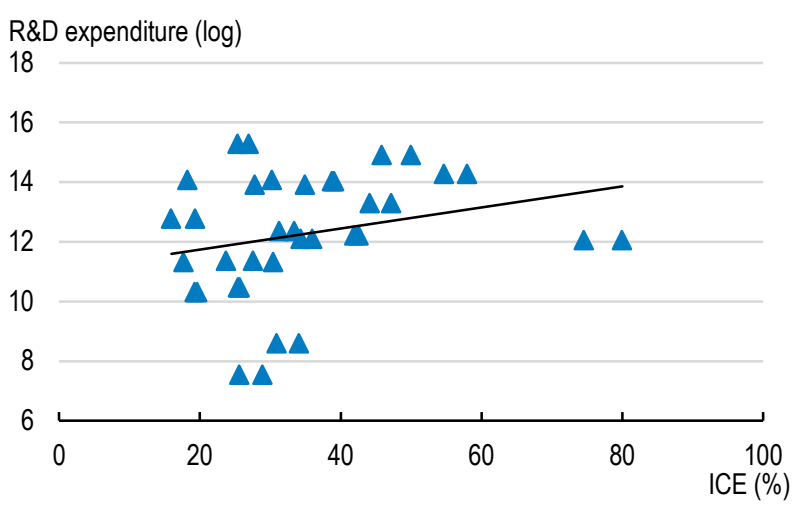

R\&D in the manufacturing sector and labour productivity

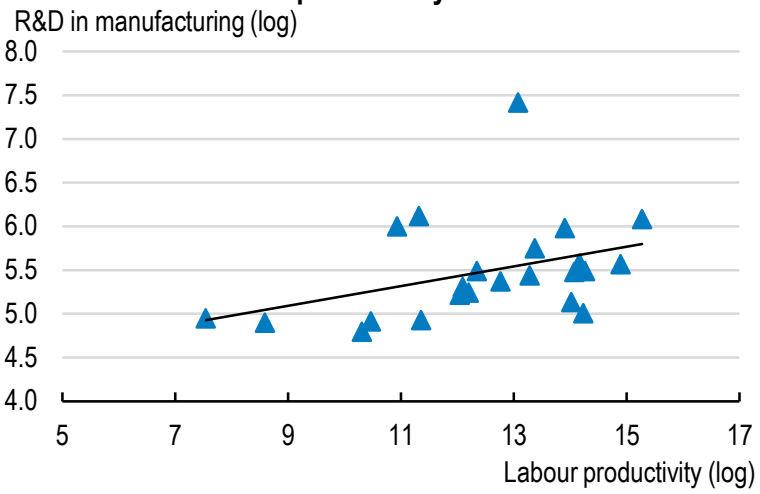

B. Productivity, backward GVC integration and innovation

Technical assets vs ICE

Stock of technical assets $(\log )$

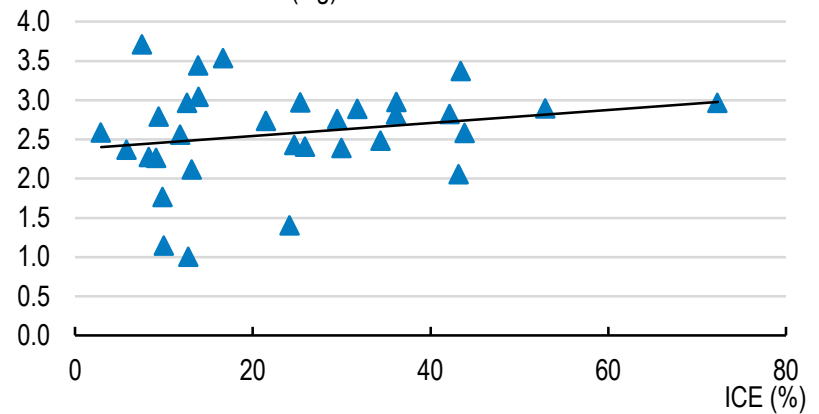

Technical assets vs productivity

Stock of technical assets $(\log )$

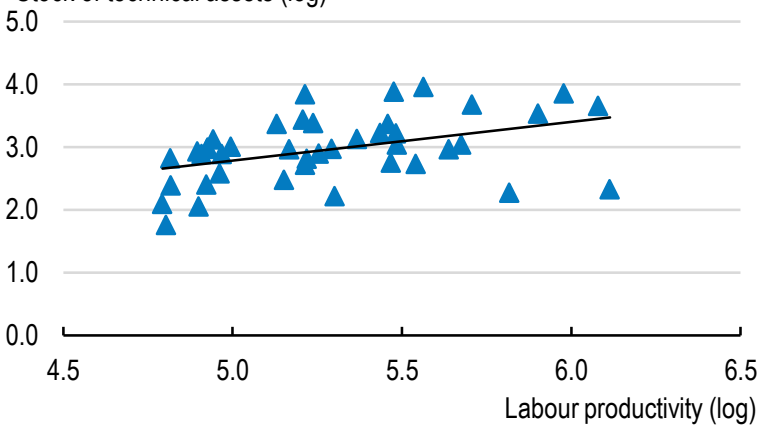

Note: Labour productivity is defined as the sector's value added per worker, in log.

Source: OECD calculation with INEGI data.

One particularly important dimension related to innovation is the ability of companies to protect their intellectual assets (OECD, 2011). Intellectual property rights (IPR) are instrumental for firms for a number of reasons: (i) to protect their innovations; (ii) to position themselves competitively vis-à-vis larger enterprises in global markets; (iii) to signal current and prospective value competitors and partners, which can help enhance access to finance; (iv) to access knowledge markets and networks; $(v)$ to open up new commercial pathways; and (vi) to segment existing markets. Patenting in Mexico has increased steadily over the last decade, together with industrial design and trademarks (Figure 19, Panel A). Yet, in international comparison, patenting activity in Mexico remains low (Figure 19, Panel B). 
Figure 19 Intellectual property activity

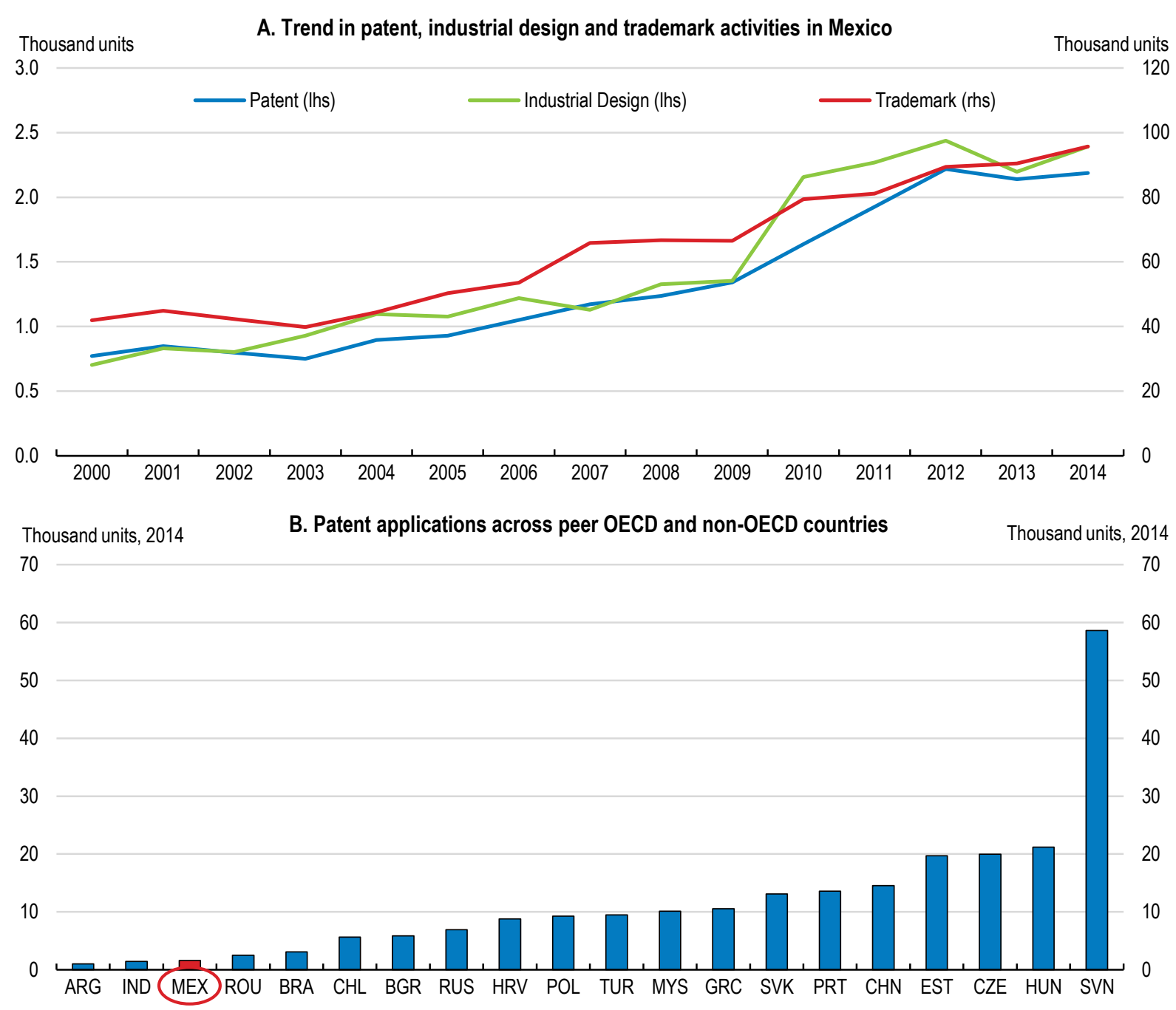

Source: WIPO, 2015; OECD Science and Technology Scorecard, 2015.

Knowledge spillovers in forward linkage typically take place through qualification and certification processes for suppliers such as ISOs (Figure 20). Indeed, increased production for foreign markets requires convergence of product standards toward international best practices and triggers virtuous feedback loops between productivity, innovation, human capital endowments and living standards. Governments can also play an important role in ensuring a productive environment for qualification and certification. In 2007, Mexico and the United States signed the Bilateral Aviation Safety Agreement (BASA). This agreement recognised the technical capabilities of Mexico's Directorate of Civil Aeronautics to certify the safety of components made in Mexico and replaced the usual re-certification need from the US Federal Administration. Thus, the agreement eliminated a step in the supply-chain since products no longer need to be examined internationally before being shipped off to consumers to undergo further assembly operations. 
Figure 20 ISO certified industries are more backward integrated in GVCs

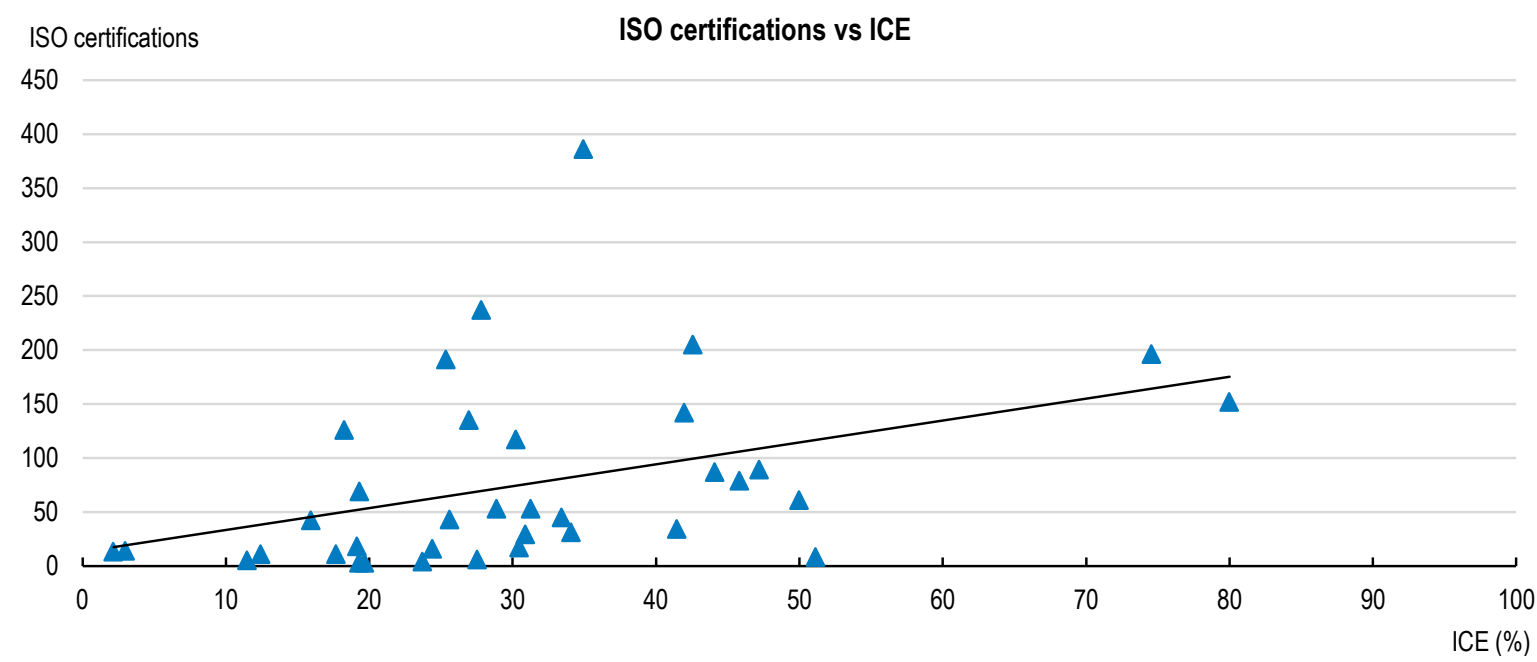

Source: Latest available year. OECD analysis using ISO and INEGI data.

\section{Skills}

One of the most important obstacles for further developing the country's knowledge base capital (KBC) potential are skills gaps and mismatches. A population with higher levels of skills is a major driver of productivity growth, thereby supporting economic prosperity and higher living standards. Across Mexican industries, the skill base, proxied by the share of workers with higher education per sector, is positively related to backward GVC integration and productivity (Figure 21). However, despite many efforts, Mexico still faces several challenges. Students' foundation skills remain weak, not many Mexicans reach and complete tertiary education, student expenditure remains low, scientific production is low, and linkages between the business sector and education institutions is among the lowest in the OECD. Currently a Skills Strategy review is being undertaken with the support of the OECD. The Action Plan will be used by the National Productivity Committee as an input to formulate binding public-private recommendations with specific milestones, designated agencies, set deadlines and performance indicators.

Figure 21 Sectors with higher educated workers are more productive and more integrated in GVCs

\section{A. Share of upper secondary educated workers vs} ICE

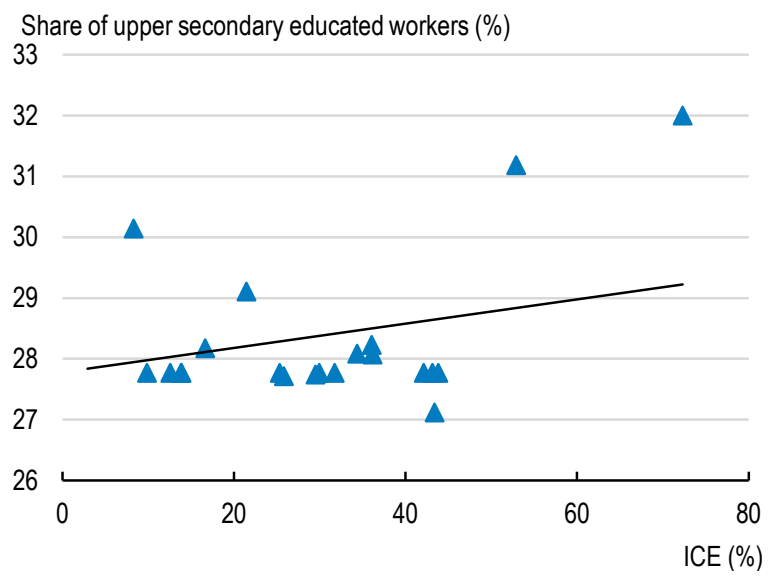

B. Share of upper secondary educated workers vs productivity

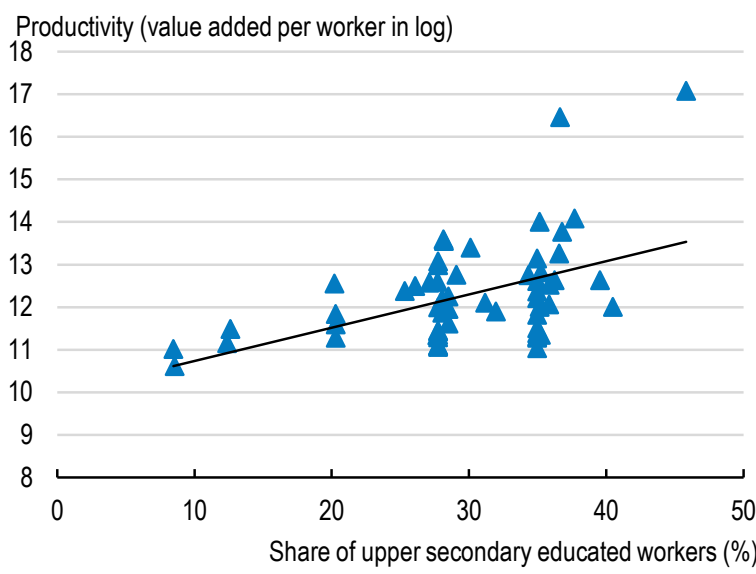

Note: Latest available year. Labour productivity is defined as the sector's value added per worker, in log. Data points refer to the manufacturing sector.

Source: OECD calculations with INEGI data. 
Tertiary education is an important link between education policies and the labour market. In Mexico, as in most OECD countries, the employment rate of adults tends to increase with educational attainment. In 2015, only $16 \%$ of adults in Mexico had attained tertiary education, the lowest share across OECD countries (Figure 22, Panel A). Still, tertiary attainment has increased considerably in recent years (OECD, 2016). With the aim of tackling these challenges, the government enacted the recent education reform which included a constitutional amendment and the design of new regulatory laws for education. These changes included the legal framework for the processes of professional development of teachers, principals and supervisors, and mandate a National Evaluation System which is now in effect. Teacher evaluations have been performed and a new education model has been announced. In addition, new programs have been introduced to improve school infrastructure such as "Escuelas al CIEN". The strategy "Escuela al Centro" was presented in early 2016 to reduce the administrative burden of schools, allowing them greater management autonomy and transferring resources directly to schools to allow them to meet its priorities faster. It is important for the government to continue with the full implementation of the reform, emphasising and rewarding the merit of teachers who do well in their job and by providing courses and training for those requiring support in order to guarantee the quality of education.

Fully unleashing the country's potential requires a comprehensive programme to better equip students with the skills demanded by employers. Mexico has a high number of firms reporting difficulties in finding the skills they require. Based in the Manpower 2015 Talent Shortage Survey, more than half of the Mexican employers (54\%) report difficulties filling jobs due to lack of available talent, a proportion that increased from previous years. Interestingly, skilled trades, engineers and production operators/machine operators are within the top five jobs employers report having difficulty filling (Manpower Group, 2015). One way to tackle skill shortages is through vocational education and training, work-based programmes and further promoting the training of students in subjects related to science, technology, and mathematics. As part of Mexico's current policy of promoting technological education, boosted by the recent Education Reform, the government has taken steps to increase the participation of youth in programmes that offer them technical training while completing their upper secondary education (e.g. CONALEP, Bécate, Modelo de Emprendedores). These programmes allow them to continue to higher education and work if needed. However, in 2014, about 38\% of all ages of students in Mexico were enrolled in vocational upper secondary education programmes, lower than the OECD average of $44 \%$. This way, only $19 \%$ of young adults in Mexico are expected to graduate from vocational programmes over their lifetime while for the OECD countries average is $46 \%$ (OECD, 2016). Likewise, the annual expenditure per student in upper secondary vocational programmes in Mexico was USD 3300 in 2013, much lower than expenditure for general programmes. In contrast, across OECD countries, expenditure is higher for vocational programmes than for general programmes, amounting to USD 10 000, over three times as high as Mexico's expenditure in absolute terms (OECD, 2016). Overall, considering the low graduation rates and low levels of expenditure in vocational education, the Mexican government still needs to enhance investment to upgrade dual education and training programmes to facilitate allocation of students to the most productive fields. The National Productivity Committee (NPC) is in the process of updating the technical training programmes for high productivity sectors, considering the deep transformations that require qualified labour. The NPC also recently issued a set of recommendations aimed at promoting dual education programmes, which will link workers to firms with the specific skills they require. 
Figure 22 Mexico's share of engineering graduates is high but lags behind in tertiary and vocational

A. Adults with tertirary education (age 25-64)

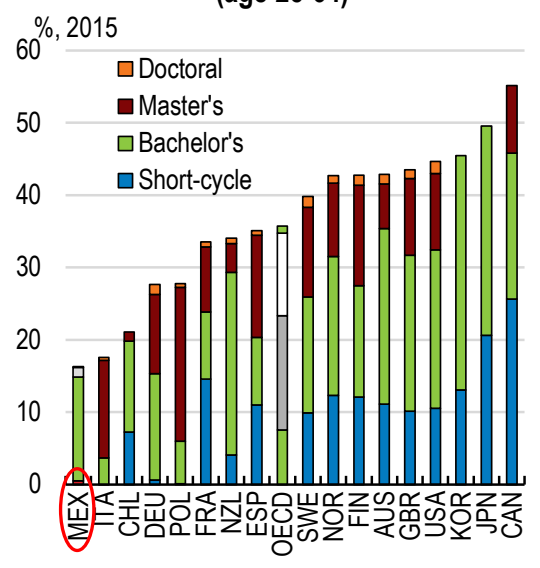

B. Share of graduates by field

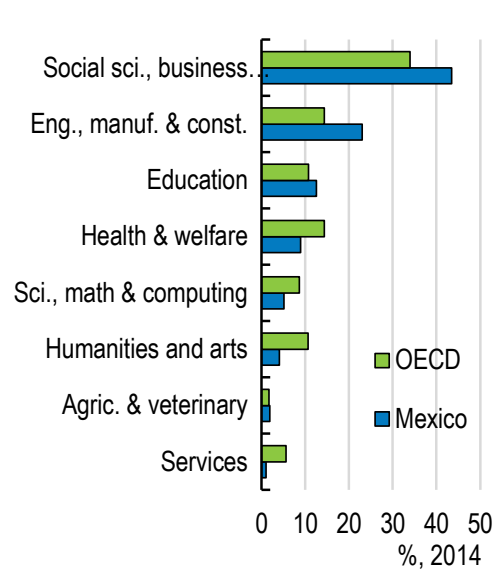

C. Share of students in vocational programmes

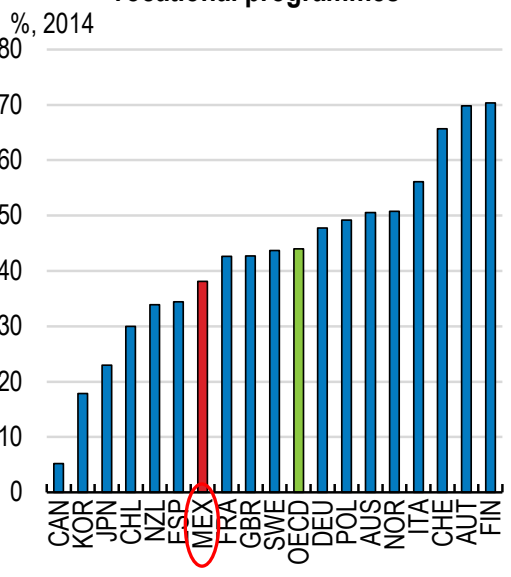

Note: Panel A: 2013 data for Chile and 2014 data for France.

Source: Education at a Glance 2016 (OECD, 2016).

\section{Competition is essential to ensure access to GVCs}

Fully leveraging GVCs requires efficient domestic markets and the removal of internal barriers to competition (OECD, 2016d). Lifting barriers to competition in goods markets can also promote integration within GVCs, and increase innovation and productivity. Lifting product market regulations can spur productivity growth through increased competition, increasing GVC participation. Productivity growth can be achieved through several channels. Firstly, increased competition and entry of new firms strengthens the efficiency incentives of incumbents and provides incumbents incentives to innovate to maintain their market position (Ben Yahmed and Dougherty, 2013). In addition, by providing easier and cheaper access to inputs, reductions in red tape can also lead to gains in downstream industries utilising these intermediates (Abe, 2013).

The lack of competitive pressure in well-protected markets contributed towards many of Mexico's problems, notably high prices, rent-seeking behaviours, weak innovation activity, and high top income concentration (MGI, 2014; OECD, 2015; Sandoval, 2016). However, the policy environment to enforce competition laws has been improved, with visible results in the areas of energy and telecoms. Examples are lower electricity and telecoms prices, successful oil auction tenders, and more intensive competition in telecoms and broadcasting. There is still much to be done, in particular the fine-tuning of new regulators' legal frameworks.

While competition agencies rely on detailed market analysis to determine presence of competition problems, some proxies of concentration by sector can also be useful heuristics to compare countries and regions. An important question is whether dominant firms can maintain their market shares over time. Standard concentration ratios based on the largest four firms appear to be highly fluid, suggesting that market dominance is not especially persistent, and has changed relatively frequently over recent periods, even tending slightly towards decreasing on the whole. 
Figure 23. High sectoral concentration is an issue in the south

Share of four-digit sectors by concentration level

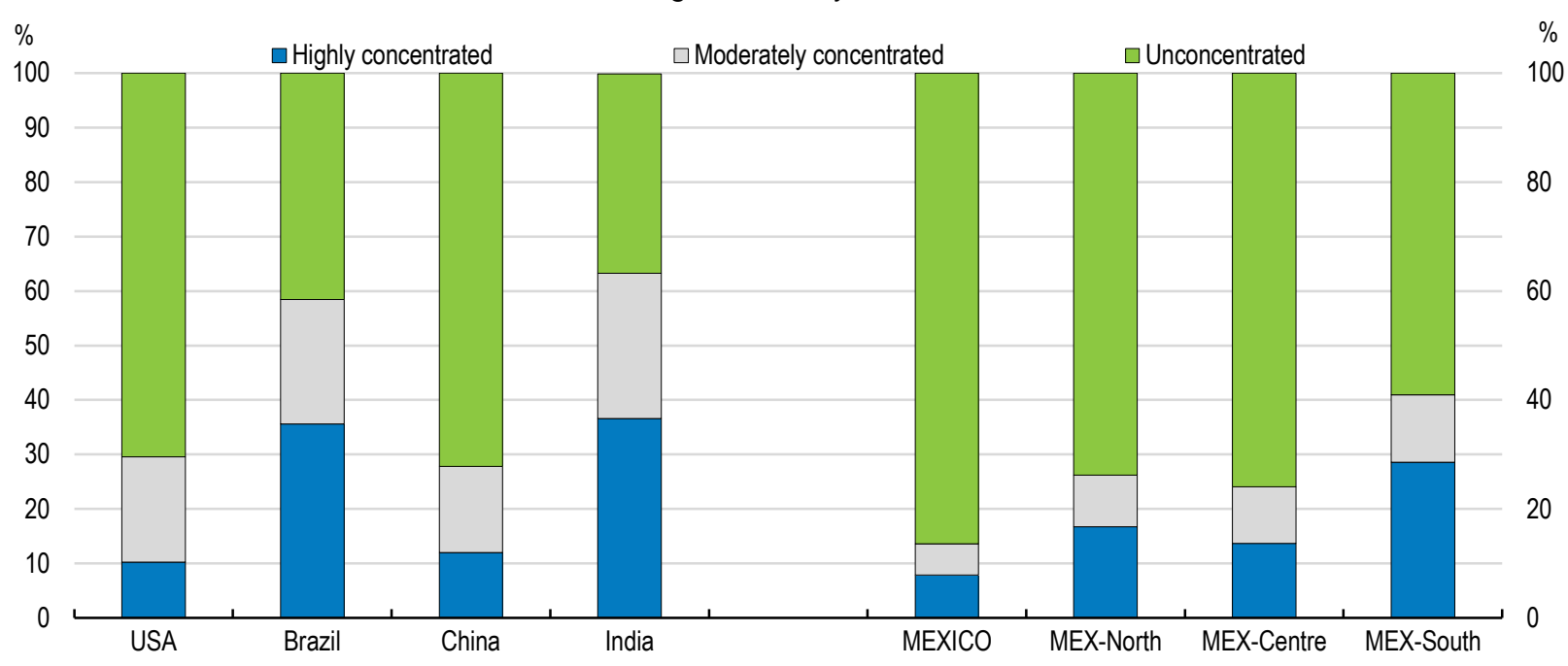

Note: Share of four-digit sectors by US Department of Justice concentration threshold using the Herfindahl-Hirschman Index (HHI). Mexico overall: 279 sectors; North region: 275 sectors; Centre region: 278 sectors; South region: 266 sectors. Note that regional indexes show higher concentration than national ones, due to market size effects on the $\mathrm{HHI}$ index.

Source: OECD calculations using economic censuses; OECD (2013b); Dougherty et al. (2009).

Another measure of concentration is the Herfindahl-Hirschman index (HHI), which can be computed using economic census microdata from INEGI. The HHI is calculated by squaring the market share of each firm competing in a sector and summing, yielding a statistic ranging from 0 (low concentration) to 1 (high concentration). Sometimes the HHI is multiplied by 10000 for convenience:

$$
H H I_{S}=10000 \sum_{i=1}^{M_{S}}\left(\frac{\text { Sales }_{S i}}{\text { Sales }_{S}}\right)^{2}
$$

Where Sales $_{s}$ is the size of the market and $M$ is the total number of firms, for each sector $s$. Following traditional US Department of Justice (DOJ) and Federal Trade Commission criterion, sectors are categorised in three groups: $i$ ) Highly Concentrated sectors if their HHI is above 0.25 (or above 2500 ), ii) Moderately Concentrated sectors if their HHI is between 0.15 and 0.25 (or between 1500 and 2500), and Unconcentrated sectors if their HHI is below 0.15 (or under 1500 ). Competition Agencies often use the HHI for evaluating potential mergers issues to be examined with additional tools.

The results suggest that, nationally, Mexico has a relatively small share of Highly and Moderately Concentrated sectors, even fewer than in the United States (Figure 23). Since what matters in many markets (such as telecoms) is regional competition, the indexes are also shown for three regions of the country. While not directly comparable due to market size effects, they give an indication of how much concentration may be an issue below the national level. Notably, concentration in the South of the country (especially for Highly Concentrated sectors) is more similar to Brazil or India, where high concentration is commonplace - in part due to sparse distribution of economic activity - while the centre and north of the country are more like the United States or China, where high sectoral concentration is much less common. 
In order to ensure that the market share shifts do not disguise underlying persistence, the probability of a single sector transitioning from one HHI/DOJ threshold to another is measured, over the 2008-2014 period (Figure 24). Nationally, the probability of Highly Concentrated sectors remaining so is 50\%; only $35 \%$ became unconcentrated. In addition, almost half (45\%) of Moderately Concentrated sectors became Highly Concentrated over this period, while 30\% remained so.

Figure 24. High sectoral concentration can be persistent

A. Transition probability nationally ${ }^{1}$

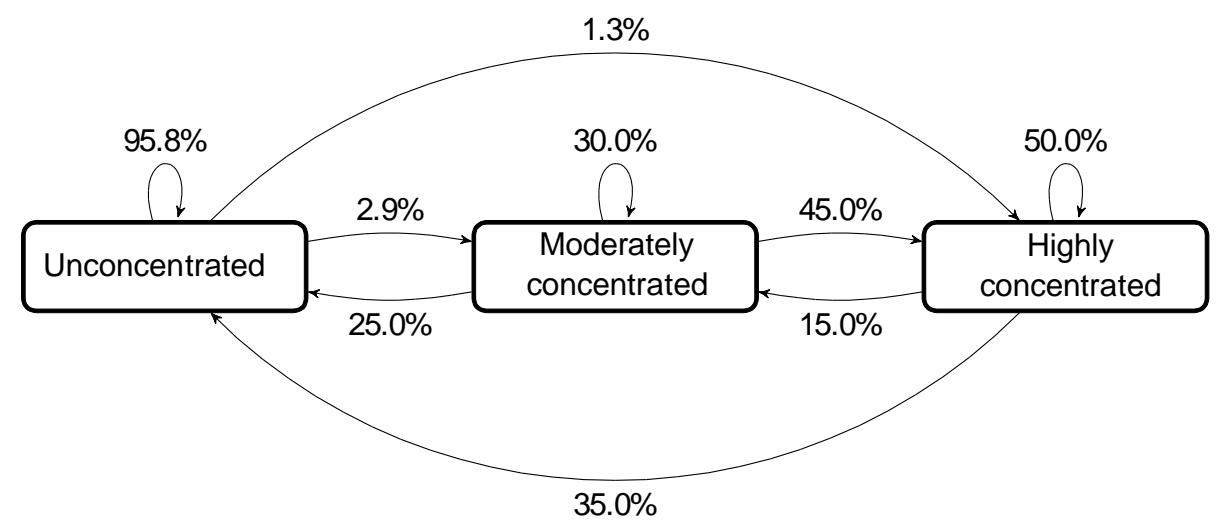

B. Transition probability in the south

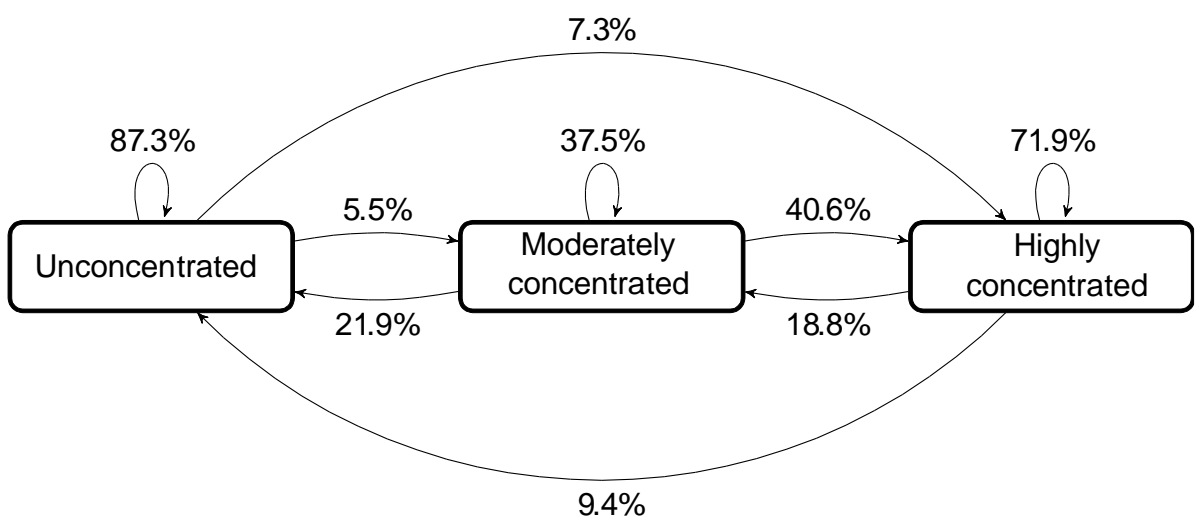

1. Probability of a four-digit sector changing US Department of Justice concentration thresholds using the HHI concentration index, over the period 2008 to 2014.

Source: OECD calculations using INEGI economic census data.

These results suggest that concerns remain about high concentration among fixed groups of customers, and within regions. For instance, what matters the most in a sector such as telecoms is whether all customers have choices, rather than the overall number of competitors in the national marketplace. Strengthened vigilance regarding regional anti-competitive practices could encourage higher productivity, further reallocation of resources to the most efficient sectors, and also help to protect consumers.

More broadly, a wide range of local regulatory barriers exist that impair entrepreneurial activity, including delays to start a business (Figure 25), which reduces effective competition. While substantial progress has been made in reviewing and identifying barriers to competition at the Federal level, much more progress is needed at the local and state levels to achieve a level playing field and ensure that new entrants are not deterred, particularly those high-productivity young firms with the potential to expand rapidly and create jobs. 
Figure 25 Entry barriers vary widely across localities

Cost to start a business

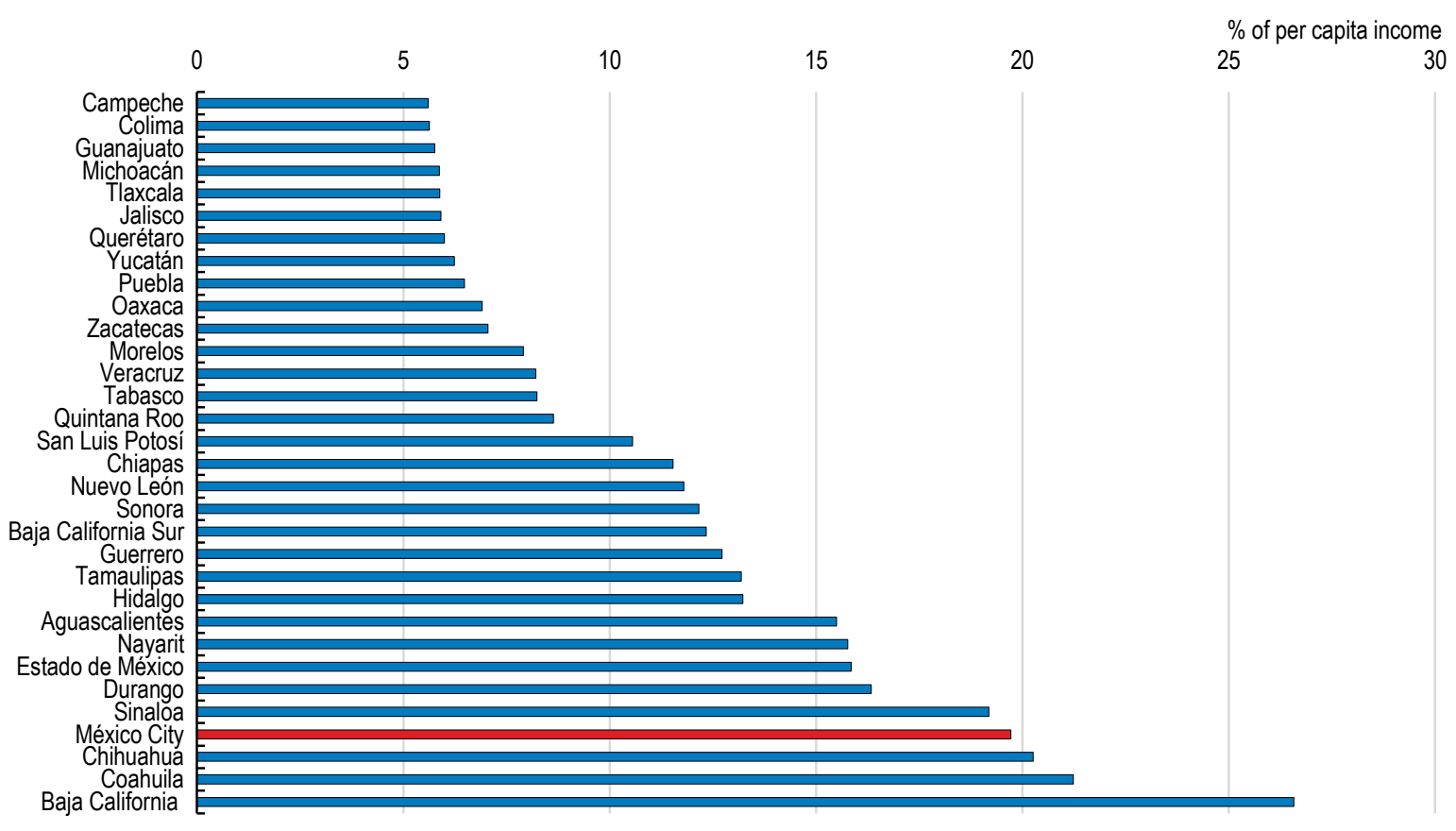

Source: Subnational Doing Business (World Bank, 2016)

\section{Are GVCs inclusive in Mexico?}

Participation of Mexican SMEs to GVCs is very limited (Figure 26, Panel A). More than $60 \%$ of domestic value added in exports is done by large firms in Mexico, most than any other OECD country. The indicator rises to $88 \%$ in the manufacturing sector, the more export oriented part of the economy (Figure 26, Panel B). Yet SMEs are the largest employers in Mexico (Figure 26, Panel C). While SMEs are vastly under-represented in GVCs when looking at direct exports only, most SMEs are plugged into GVCs as domestic suppliers of exporters. Evidence from the World Bank and the OECD shows that the indirect contribution of SMEs is sizable in most OECD countries, yet the share of both direct and indirect contributions to export value-added of SMEs in Mexico is among the lowest across OECD countries. 
Figure 26 Contribution of SMEs to GVCs in Mexico

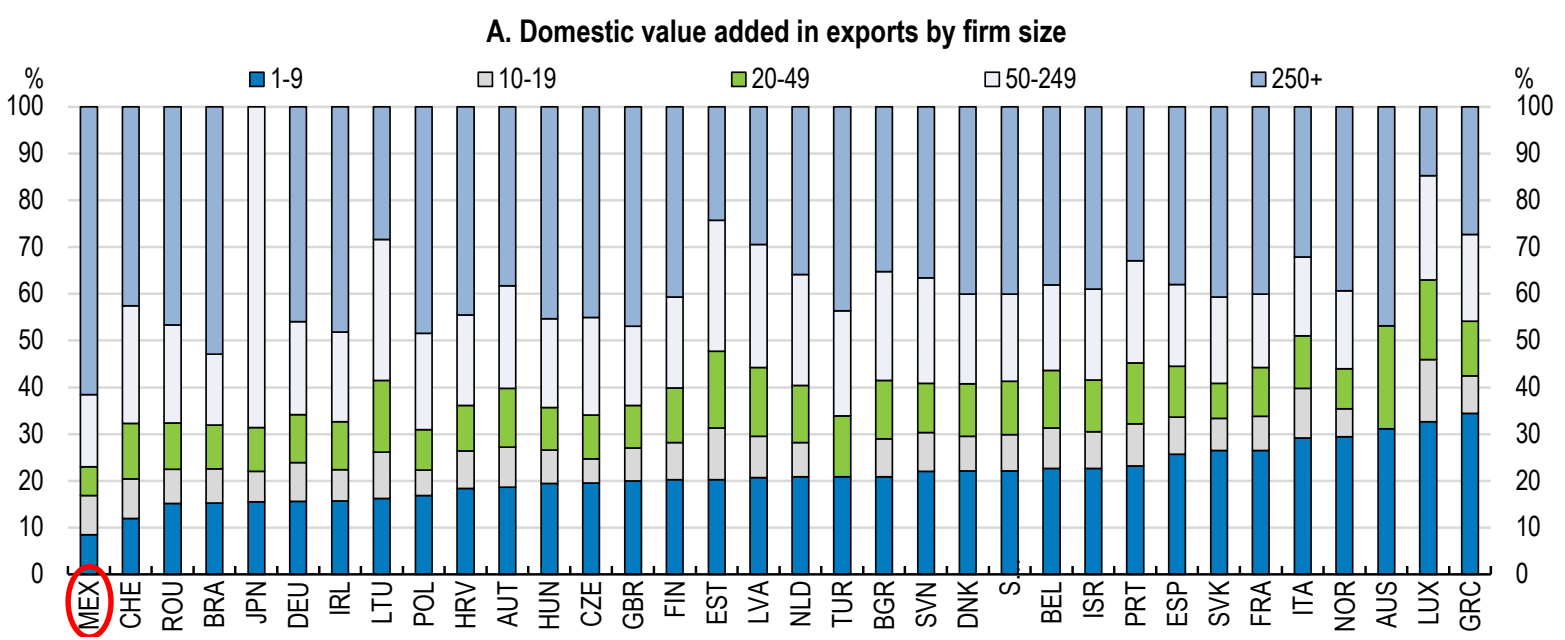

B. Domestic value added in manufacturing exports by large firms
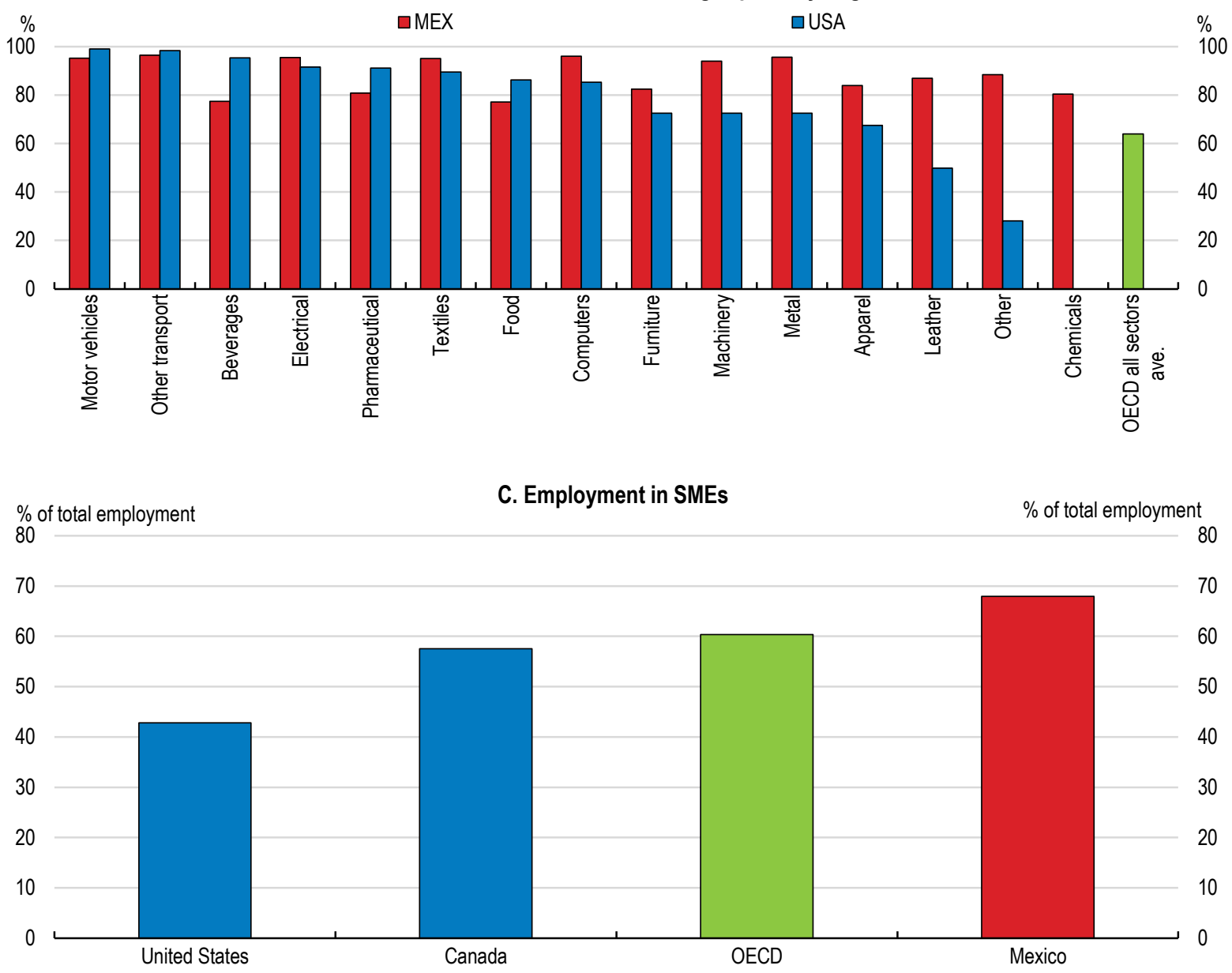

Source: OECD (2016b), OECD/Eurostat Trade by Enterprise Characteristics (TEC) database, OECD Structural and Demographic Business Statistics (SDBS) database, OECD-WTO TiVA database. 
GVCs operate in formal markets. Yet, the majority of firms in Mexico are informal (Figure 27, Panel A), similar to many other emerging economies. Informality is a problem for productivity, to the extent that resources are misallocated. Almost half of Mexico's informal workers are employed in extremely small, informal firms (Figure 27, Panel B), which suffer from especially low productivity. The challenge to make GVCs more inclusive in Mexico should therefore focus on policies to support the formalisation of firms and workers. These small firms' productivity could potentially be boosted substantially if these firms were induced to grow or exit. OECD analysis supports the idea that a wide range of policies can have an impact on informality, including boosting labour skills, tackling corruption, increasing foreign investment, enhancing tax enforcement and reducing entry barriers (Dougherty and Escobar, 2013; OECD, 2013b, 2015).

Figure 27 Informality and productivity by firm size

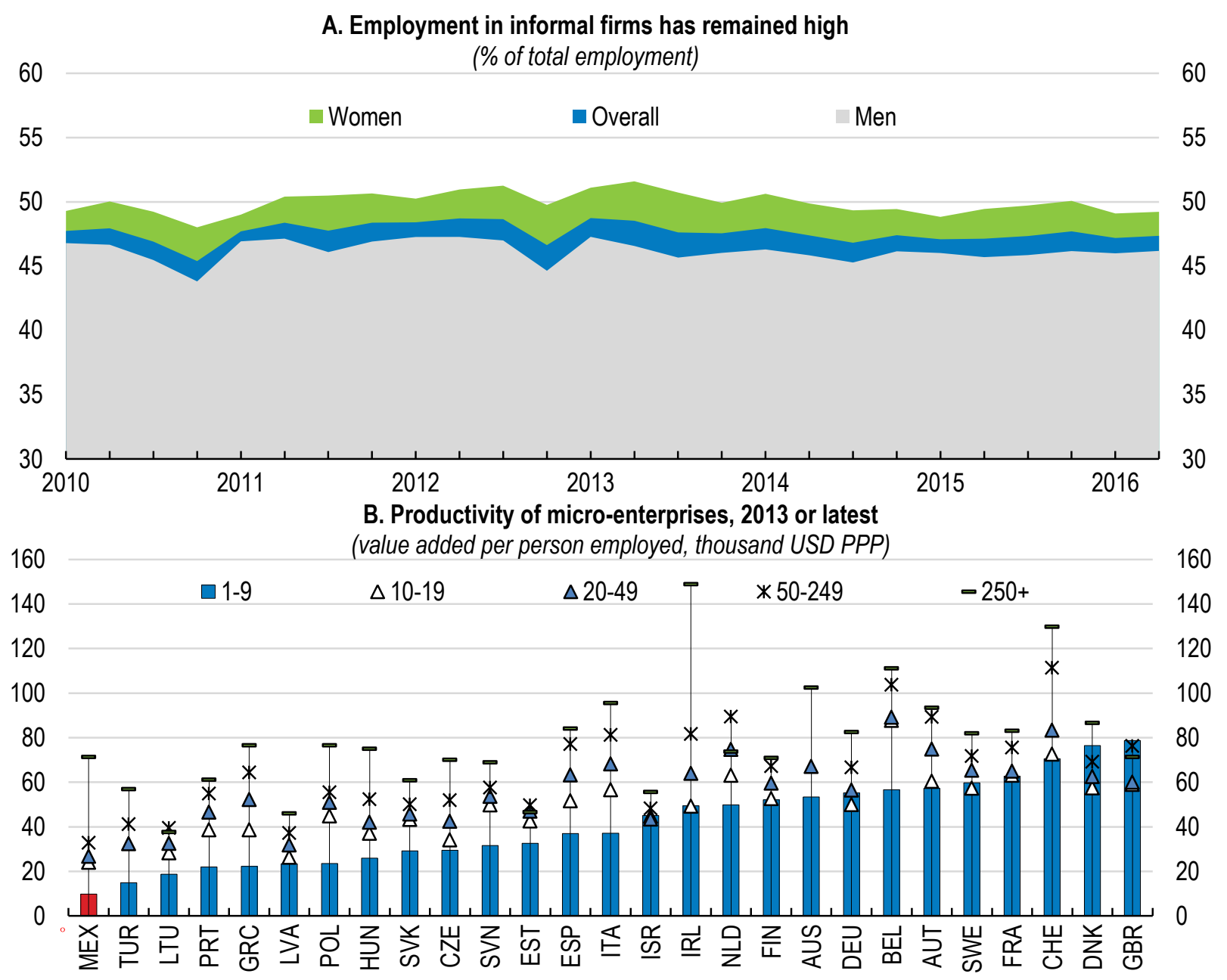

Note: Panel B: MEX: data refer to 2014, IRL: 2011, ISR: 2012. Data for the GBR exclude an estimate of 2.6 million small unregistered businesses. CHE: data refer to employees. MEX data refer to establishments.

Source: INEGI and OECD calculations; OECD and World Bank (2015); OECD SDBS database. 
One of the main causes of the productivity gaps by firm size are gaps in management skills and management practices between small and large firms. A recent OECD study shows that gaps in management skills and practices between small enterprises (less than 50 employees) and large companies (over 250 employees) are substantial across five dimensions: manager's experience; ownership of a business website; performance of in-house worker training; international quality certifications; and audited financial statements (OECD, 2016c). Performance on each of these dimensions is positively linked to labour productivity at the firm level. While Mexico does score relatively high for most of the dimensions of management skills, it does score relatively low for audited financial statements, which is linked to informality, the dimension estimated to have the largest contribution to productivity.

Effective enforcement of laws is crucial for a good business environment, ensuring that contracts are reliably enforced, and in order to engage in trade. Empirical estimates suggest that a low-quality judiciary makes contract enforcement and insolvency procedures problematic, lowering the average size of firms and their capital intensity (Palumbo et al., 2013), thus reducing aggregate productivity substantially (Dougherty, 2014). Revised estimates with the latest data confirm these relationships, and lend particular support for the importance of strengthening budgetary resources for the judiciary (Gann, 2016). Moreover, the quality of the legal system is more than twice as important for small firms' growth as for larger firms', since the later often have the option to vertically integrate.

Major legal reforms of the civil and commercial justice are still to be fully acted upon, although a start has been made for larger cases. The OECD has estimated that such reforms could add $1 / 2$ of a percentage point to GDP growth in the medium term (OECD, 2015). Large efficiency gains from transitioning from written to oral trials could also help to improve the outcomes of economic disputes such as those related to contract enforcement. The new procedures are now only applied to the largest cases, and not in all jurisdictions. The concerted efforts that have been made to adopt the new procedural reforms for criminal cases need to also be fully extended to apply for all civil and commercial cases.

\section{Estimates of misallocation help to see the potential upside of reform}

The ability of an economy to reallocate resources to the most efficient firms that translates the efficiency gains obtained at the frontier into higher aggregate productivity levels and growth rates (Andrews et al., 2015). Recent research suggests that the contribution of the efficiency of reallocation to aggregate productivity levels could be sizeable, and is linked to informality in the case of Mexico (Box 3). In a healthy economy the firms that are initially most productive or successfully innovating should be able to attract a larger and increasing share of employment and capital to finance their investment relative to their less productive and stagnating peers. Recent and ongoing research shows that this ability varies widely across countries and can also change over time. 


\section{Box 3. How does Mexico's productivity dispersion compare with China's?}

Spectacular growth during the 1990s and early 2000s in China made it the envy of the World. Yet more recently, relative labour costs have risen substantially in China, and economies such as Mexico's, which lost export market share for some time, have made a partial comeback. However, Mexico's increasing competitiveness masks one of the country's fundamental concerns, which is weak productivity. Dougherty and Escobar (2016a) examined the evolution of multifactor productivity in Mexico's manufacturing sector, as compared to China's. Firm-level micro-data were used to examine the distribution of productivity across Mexico's states, and also to track the misallocation of resources. Multi-factor productivity differs considerably across firms and regions. While Mexico's most productive firms are performing relatively well, and can compete with China's, the vast majority of firms are struggling to perform better with limited success, leading to a growing dispersion in productivity (Figure 28). An analogous situation is observed in other OECD countries where there is a rising gap in productivity between the most advanced firms and the laggards, and the gains in productivity of the most advanced firms are not enough to improve aggregate productivity.

Mexico's federal structure can be used to identify drivers of productivity, using econometric techniques to address potential reverse causality issues using instruments. Findings suggest that among various factors, a stronger rule of law increases productivity in Mexico. This is robust to previous OECD evidence, which suggests that firms in Mexico's states with more effective legal systems tend to be substantially larger and more productive (Dougherty, 2014).

The results also show that among the institutional quality-related variables, informality has the strongest effect on productivity for Mexico. Moreover, informality is seen as a source of distortions that contribute to the misallocation of resources. The results imply a strongly negative relationship between informality and productivity. Among different sized firms, informality in microenterprises (up to 10 workers) has the strongest negative effects on productivity. This evidence also suggests - in a new finding - that more productive states and industries suffer more from informality than less productive ones. This is likely due to resources being perversely tied up in informal activities, akin to the 'Zombie firms' problem. Tackling informality is a complex challenge, and one that requires a multi-faceted approach (OECD, 2013b, 2015).

Research findings also suggest that the presence of foreign investment improves productivity - with the exception of Maquiladora industries, which are missing out on productivity gains. This is likely due to Maquila's undue emphasis on low-end, low-skill assembly operations, which have often not fared very well in competition with China. Moreover, weak education quality simultaneously acts as a major restraint on productivity and aggravates informality.

\section{Figure 28. Aggregate TFP growth and firm-level dispersion}

Mexico's states are shown in red and China's provinces in blue

0.4

Aggregate TFP growth (\%)

NX

0.3

$$
\triangle \text { Mexico } \quad \text { - China }
$$

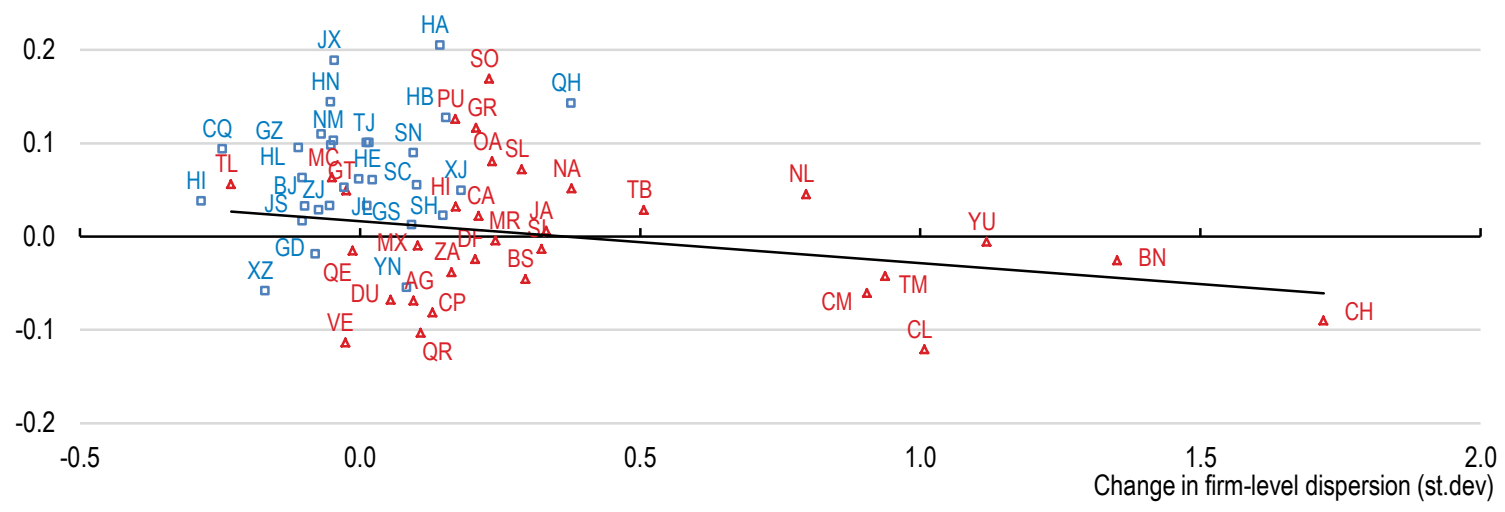

Note: Dispersion is measured as the standard deviation of firm-level productivity.

Source: OECD calculations based on INEGI data. 
Earlier OECD simulations based on time-series relationships at the industry-state level suggest that economy-wide total factor productivity growth could be boosted by up to $1 / 2$ percentage point, if informality were reduced by 10 percentage points (OECD, 2015; Dougherty and Escobar, 2016a). However, such estimates are rough, based on only one type of distortion (informality), and do not explain the mechanisms behind these economic distortions. In order to better understand what could drive such large shifts in productivity, a more micro-grounded general equilibrium analysis is needed. Thus, the extent of capital and labour misallocation across firms in Mexico, and the effect on total factor productivity is estimated in this section, using "cutting-edge" techniques with the latest microdata (Box 4), following the approach of Hsieh and Klenow (2009).

Results of the analysis imply that misallocation is extreme in Mexico, close to that of India. Moreover, productivity was stagnant from 2008 to 2014, mainly because of factor misallocation. The distribution of factor allocation has not improved, and there is a slight increase in the dispersion of total factor productivity within the manufacturing sector. This dispersion is mainly due to the increasing gap between the most and the least productive firms, where the ratio of TFP for firms in the $90^{\text {th }}$ percentile to the bottom $10^{\text {th }}$ percentile has increased from 15.4 to 18.4. Contrastingly, the economy-wide $90 / 10$ dispersion has declined slightly, from 23.7 to 21.5 , driven by services.

\section{Box 4. Modelling misallocation}

The Hsieh and Klenow (2009) model of monopolistic competition with heterogeneous firms is employed, and adapted to Mexico's case. Let the value added $Y$ production function for each plant $i$ of industry $s$ be a Cobb-Douglas function of firm TFP $A$, capital $K$, and labour $L$ :

$$
Y_{s i}=A_{s i} K_{s i}^{\alpha_{s}} L_{s i}^{1-\alpha_{s}}
$$

where capital and labour shares are allowed to vary across industries, but not plants within an industry.

Following Foster et al. (2008), a distinction is made between physical productivity (TFPQ) and revenue productivity (TFPR). TFPQ can be obtained when using a plant-specific deflator, whereas TFPR can be computed using an industry deflator. Although plant-specific deflators are not available (per usual), we can focus on TFPR, which can be defined as follows:

$$
T F P R_{s i}=P_{s i} A_{s i}=\frac{P_{s i} Y_{s i}}{K_{s i}^{\alpha_{S}} L_{s i}^{1-\alpha_{S}}}
$$

where $P_{s i}$ is a firms' output price.

Plants face output and capital distortions that influence both their output and factor allocation. Output distortions ( $\left.T_{Y}\right)$ are those that increase the marginal products of both capital and labour. For instance, $T_{Y}$ would be high for plants facing government restrictions, but low for those benefiting from government subsidies. Capital distortions $\left(I_{K}\right)$ are those that increase the marginal product of capital relative to labour. For instance, $T_{K}$ would be high for plants facing problems to access to credit, but low for those plants that have access to cheap credit. Since these distortions influence resource allocation within each firm, there would be differences in the marginal revenue products of labour and capital across firms. Assuming that all firms face the same wage (w). Hsieh \& Klenow (2009) show that, before taxes, plant is marginal revenue product of labour $(M R P L)$ and marginal revenue product of capital $(M R P K)$ can be expressed as a function of these distortions. Hsieh and Klenow (2009) also show that we can define TFPR as a function of marginal revenue products of capital and labour, and thus as a function of distortions:

$$
T F P R_{s i}=\frac{\sigma}{\sigma-1}\left(\frac{M R P K_{S i}}{\alpha_{s}}\right)^{\alpha_{s}}\left(\frac{M R P L_{s i}}{1-\alpha_{s}}\right)^{1-\alpha_{s}}
$$

where $\boldsymbol{\sigma}$ is the elasticity of substitution.

(Box continued.....) 


\section{Box 4. Modelling misallocation (Box continued)}

Similarly, we can define the average TFPR of the industry $s$ as a geometric average of the average marginal revenue product of capital $\sigma$ and labour in the sector. In the absence of distortions TFPR does not vary across plants within an industry, and then $\sum_{i=1}^{M_{S}} T F P R_{s i} / \overline{T F P R}_{S}=1$.

In this case, more capital and labour should be allocated to plants with higher TFPQ until their increase in output results in a reduction of price and the exact same TFPR as at smaller plants. On the other hand, output and capital distortions generate differences in the marginal revenue products, favouring an allocation of resources in firms that benefit from subsidies and cheap access to credit. Thus, the term $\sum_{i=1}^{M_{S}} T F P R_{S i} / \overline{T F P R_{S}}$ increases as output and capital distortions increase.

\section{Treating the microdata}

To analyse TFPR and the extent of resource misallocation in Mexico, one can focus on the distribution of a variable defined as term $\log \left(T F P R_{S i} / \overline{T F P R}{ }_{S}\right)$. If the standard deviation of this variable decreases, we can then deduce that the allocation of resources has become more efficient. On the contrary, an increase of the standard deviation of this variable is a sign of an increase of resource misallocation.

In order to measure output and capital distortions, the approach of Hsieh \& Klenow (2009) is used, and the rental price of capital without distortions is set to $R=1$, and the elasticity of substitution to $\sigma=3$. First, output distortions are inferred when the labour's share is low relative to what one would expect from the industry elasticity of output with respect to labour:

$$
1-\tau_{Y_{s i}}=\frac{\sigma}{\sigma-1} \frac{w L_{s i}}{(1-\alpha) P_{s i} Y_{s i}}
$$

Second, a capital distortion is assumed when the ratio of labour compensation to the capital stock is high relative to what one would expect from the output elasticities with respect of capital and labour:

$$
1-\tau_{Y_{s i}}=\frac{\sigma_{s}}{1-\sigma_{s}} \frac{w L_{s i}}{R K_{s i}}
$$

To compute marginal revenue products and estimate the elasticity of output with respect to capital $\left(\alpha_{s}\right)$, data are needed on wage payments, output, units of labour, and capital stock. Plant-level data on wage payments, output, units of labour, and capital stock are from INEGI's 2009 and 2014 economic censuses. Economic censuses are conducted every five years, and cover all economic units in the country. From this survey, we use information on plants' valueadded $\left(Y_{s i}\right.$ in the model), wage payments $\left(w_{s i}\right)$, hours worked $\left(L_{s i}\right)$, capital stock $\left(K_{s i}\right)$, and industry $(s)$ at the NAICS four-digit level.

In order to understand the overall effects of misallocation, the productivity distribution is compared with one without distortions. According to the model, $T F P R_{S i} \approx \overline{T F P R}_{S}$ in the absence of output and capital distortions. The effects of an efficient factor allocation of plants' value added are then estimated as $\overline{P_{s l} Y_{s l}}=\overline{T F P R} K_{s i}^{\alpha_{s}} L_{s i}^{1-\alpha_{s}}$.

In order to understand the full scope for structural reforms to have an impact, a comparison of Mexico's economy is made to one without allocative distortions, in Table 2. This suggests that the overall gain could be an increase of $200 \%$ of firm-level value added, which is truly enormous, although in a similar range to other recent studies (Busso et al., 2012). Moreover, the smaller firms (the bottom quartile in terms of value added) would experience even larger average gains, of almost $400 \%$. In the manufacturing sector, the average increase would be almost as large (390\% gain), with $45 \%$ of firms experiencing gains of more than $200 \%$. Also in manufacturing, smaller firms could benefit the most from efficient factor allocation, with estimated gains of $748 \%$ (an eight-fold gain). 
Table 2. Gains from a more efficient allocation of production factors

\begin{tabular}{|c|c|c|c|c|c|}
\hline & \multirow[b]{2}{*}{$\begin{array}{c}\text { Average gain (\% of } \\
\text { value added) }\end{array}$} & \multicolumn{4}{|c|}{ Share of firms with gains of } \\
\hline & & Under $50 \%$ & $\begin{array}{c}\text { Between } 50 \% \\
\text { and } 100 \%\end{array}$ & $\begin{array}{c}\text { Between } 100 \% \\
\text { and } 200 \%\end{array}$ & $\begin{array}{c}\text { More than } \\
200 \%\end{array}$ \\
\hline \multicolumn{6}{|l|}{ All the economy } \\
\hline Top size quartile & 96.4 & 63.0 & 9.4 & 10.8 & 16.7 \\
\hline 2nd quartile & 130.4 & 58.6 & 10.0 & 11.8 & 19.7 \\
\hline 3rd quartile & 197.9 & 50.3 & 10.6 & 13.1 & 25.9 \\
\hline Bottom quartile & 393.4 & 32.4 & 9.8 & 14.5 & 43.4 \\
\hline All & 205.1 & 51.0 & 10.0 & 12.6 & 26.5 \\
\hline \multicolumn{6}{|l|}{ Manufacturing } \\
\hline Top size quartile & 206.3 & 43.4 & 10.6 & 14.5 & 31.5 \\
\hline 2nd quartile & 244.7 & 37.6 & 11.2 & 15.6 & 35.5 \\
\hline 3rd quartile & 359.0 & 25.6 & 10.0 & 16.7 & 47.7 \\
\hline Bottom quartile & 748.4 & 16.6 & 6.0 & 11.4 & 66.1 \\
\hline All & 390.6 & 30.8 & 9.4 & 14.5 & 45.2 \\
\hline
\end{tabular}

Source: OECD analysis of INEGI economic census microdata.

Put differently, within manufacturing, more efficient allocation of productive factors across the bottom three-quarters of manufacturing firms could amount to some 2.4 percentage points of GDP (taking account of their relative weight); a similar more efficient allocation of factors across all types of firms could boost GDP by 5.9 percentage points (see Dougherty and Escobar, 2016b).

The actual distribution of plants can be compared with the "distortion-free" distribution for the most recent year, using the Hsieh-Klenow approach (Figure 29). In the overall economy, the exercise suggests that there should be more large plants, in terms of value-added. However, in the manufacturing sector, Mexico could experience a significant reduction of smaller firms and an important increase in middle-sized ones. Such a reallocation of resources from low to high-productivity industries would boost Mexico's economic prospects substantially.

\section{Figure 29. More efficient factor allocation could shift out the productivity distribution}

Estimated density using plant-level data
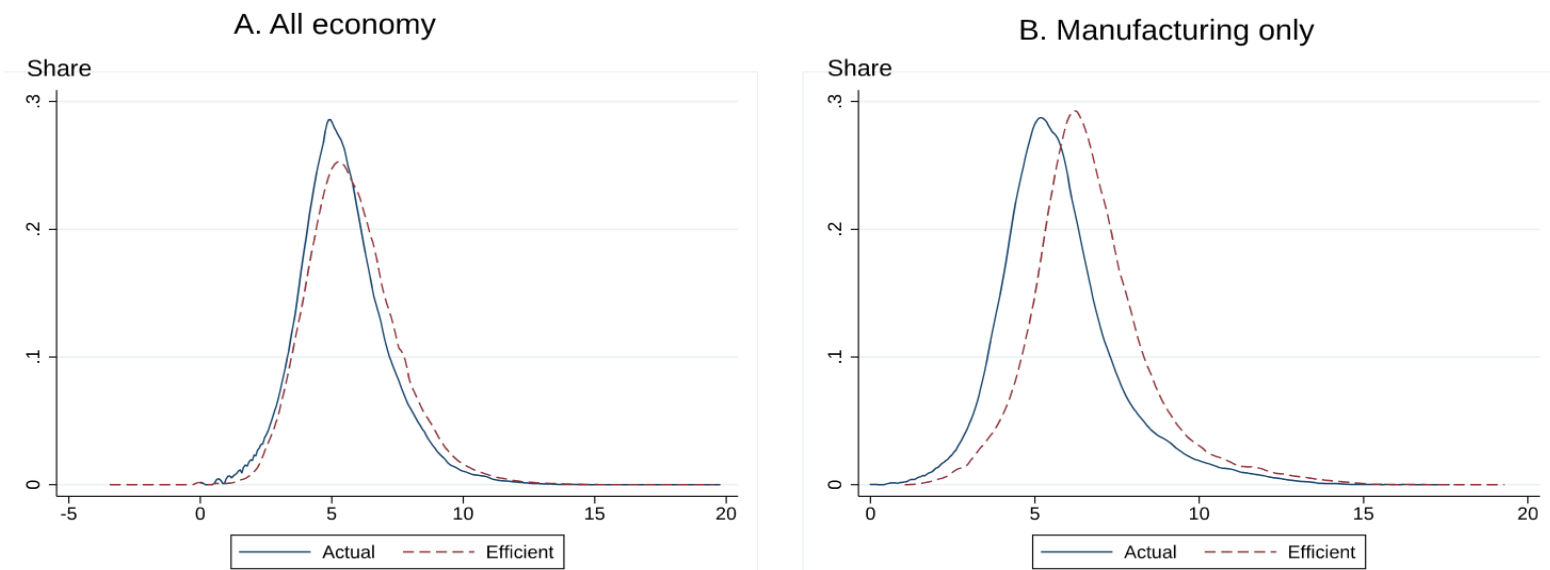

Note: Figures illustrate the kernel density distribution functions of $\log$ (value added) using 2014 economic census data, where the efficient distribution is estimated using the Hsieh \& Klenow (2009) approach.

Source: OECD calculations using INEGI economic census microdata. 


\section{The dark side of GVCs}

This paper ends with a caveat. Globalisation has made it easier for local risks to become global. Global value chains (GVCs) have recently acted as important channels of contagion, because of their global network character. Local demand and supply shocks that start in one part of the global economy can spread rapidly to the entire world. While firms are the first in line to manage the risks of GVCs, governments also have an important role, since disruptions in GVCs can have major political, economic and security implications for national economies. Because of its high integration with the United States value chain, Mexico is highly exposed to demand shocks (Figure 30). During the Great Recession, sectors and states more integrated to GVCs were hit the most. But they ultimately rebounded stronger. In this respect, the government is supporting, e.g. through the investment promotion agency PROMEXICO, further diversification of export markets.

\section{Figure 30 Vulnerability to demand shocks in GVCs, by economy}

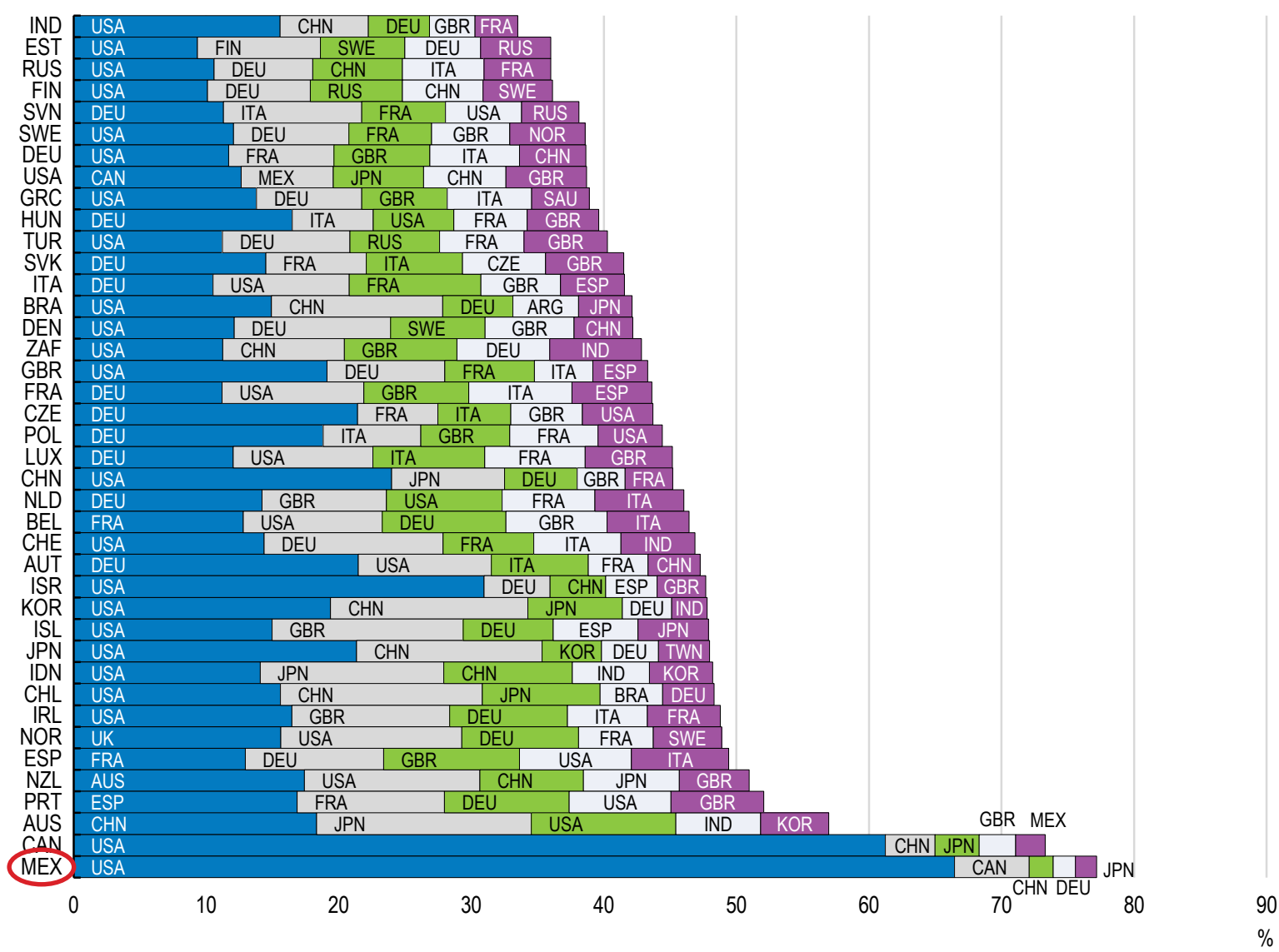

Source: OECD-WTO (2009): Statistics on Trade in Value Added database. 


\section{Policy recommendations to boost productivity}

\section{Key recommendations}

- Strengthen awareness of in-work subsidies for formal workers. Focus enforcement on large formal firms employing informal workers.

- Focus financing on early stages of co-operation of public research institutes and innovative private businesses. Continue to improve the business environment, including for foreign innovative firms.

- Build capacity of the sub-national level entities involved in the new anti-corruption system.

- Extend oral trials to all civil and commercial cases. Boost training, resources and technology for the judiciary.

- Make transfers to Mexican states conditional on implementing the national standard-setting for primary and secondary teacher performance.

\section{Other recommendations}

- $\quad$ Reduce barriers to foreign investment and services trade in important sectors for GVC integration such as logistics. Limit non-tariff measures (NTMs).

\section{REFERENCES}

Abe, M. (2013), "Global supply chains: why they emerged, why they matter, and where they are going", in D.K. Elms and P. Low (eds.), Global value chains in a changing world, WTO Publications.

Adalet McGowan, M. and D. Andrews (2016a), "Insolvency Regimes and Productivity Growth: A Framework for Analysis", OECD Economics Department Working Papers, No. 1309.

AMIA (2014), "Inventario de capacidades nacionales para el desarrollo tecnológico automotriz".

Andrews, D. and C. Criscuolo (2013), "Knowledge based capital, innovation and resource allocation", OECD Economics Department Working Papers, No. 1046.

Ben Yahmed, S. and S. Dougherty (2013), "Import Competition, Domestic Regulation and Firm-Level Productivity Growth in the OECD”, Paris School of Economics G-MonD Working Papers, No. 38.

Boston Consulting Group (2008), "Mexico's Evolving Sweet Spot in the Globalization Landscape”, BCG.

Boston Consulting Group (2014), "The Shifting Economics of Global Manufacturing: How Cost Competitiveness Is Changing Worldwide", The Boston Consulting Group, Inc. 
Busso, M., Fazio, M. V., \& Algazi, S. L. (2012). “(In) Formal and (Un) Productive: The Productivity Costs of Excessive Informality in Mexico", IADB Working Papers, No. IDB-WP-341.

Chavez Martin del Campo, J.C. and K. Garcia Loredo (2015), "Identificación de Clusters Regionales en la Industria Manufacturera Mexicana", Banco de Mexico Working Papers, No. 2015-19.

De Backer, K. and S. Miroudot (2013), "Mapping Global Value Chains", OECD Trade Policy Papers, No. 159.

Dougherty, S. and O. Escobar (2013), "The determinants of informality in Mexico's states", OECD Economics Department Working Papers, No. 1043, revised.

Dougherty, S. (2014), "Legal reform, contract enforcement and firm size in Mexico", Review of International Economics, Vol. 22, No. 4.

Dougherty, S. and O. Escobar (2016a), "Could Mexico become the new 'China'? Policy drivers of firmlevel competitiveness”, OECD Productivity Working Papers, No. 4.

Dougherty, S. and O. Escobar (2016b), "Misallocation and competition in Mexico", OECD Economics Department and Paris School of Economics, Manuscript.

Foster, L., Haltiwanger, J., and Syverson, C. (2008), "Reallocation, firm turnover, and effiency: Selection on productivity or profitability?", American Economic Review, Vol. 98, No. 1.

Gann, A. (2016), “The Impact of Judicial Quality on Firm Size in Mexico”, Paris School of Economics, Public Policy and Development Master's Thesis.

Griffith, R., S. Redding and J. Van Reenen (2004), "Mapping the two faces of R\&D: Productivity growth in a panel of OECD industries", Review of Economics and Statistics, Vol. 84, No. 4.

Hidalgo, C. and R. Hausmann (2009), "The building blocks of economic complexity", PNAS, Vol. 106 No. 26.

Hsieh, C-T and P. Klenow (2009), "Misallocation and Manufacturing TFP in China and India", Quarterly Journal of Economics, Vol. 129, No. 3.

Inklaar, R., A. Lashitew and M. Timmer (2016), "The role of misallocation and in cross-country differences in manufacturing", Macroeconomic Dynamics, January.

Javorcik, B., and M. Spatareanu (2008), "To share or not to share: Does local participation matter for spillovers from foreign direct investment?", Journal of Development Economics, Elsevier, Vol. 85, No. 1-2.

Manpower Group (2015), 2015 Talent Shortage Survey, ManpowerGroup.

Nishioka, S. and M. Ripoll (2012), "Productivity, trade and the R\&D content of intermediate inputs", European Economic Review, Vol. 56, No. 8.

OECD (2013), Supporting Investment in Knowledge Capital, Growth and Innovation, OECD Publishing, Paris, http://dx.doi.org/10.1787/9789264193307-en 
OECD (2013a, 2015), OECD Economic Surveys: Mexico, OECD Publishing, Paris, www.oecd.org/eco/surveys/economic-survey-mexico.htm

OECD (2013b), OECD Economic Surveys: Brazil 2013, OECD Publishing, Paris, http://dx.doi.org/10.1787/eco_surveys-bra-2013-en

OECD (2015a), "Developing countries participation in global value chains and its implications for trade and trade related policies", OECD Trade Policy Papers, No. 179, OECD Publishing.

OECD (2015b), "Trade in value added: Mexico", OECD-WTO TiVA country notes, OECD Publishing.

OECD (2015c), The Future of Productivity, OECD Publishing, Paris, http://oe.cd/GFP.

OECD (2016a), "Participation in Global Value Chains in Latin America: Implications for Trade and TradeRelated Policy", OECD Trade Policy Papers, No. 192.

OECD (2016b), Entrepreneurship at a Glance 2016, OECD Publishing, Paris, http://dx.doi.org/10.1787/entrepreneur aag-2016-en

OECD (2016c), Increasing productivity in small traditional enterprises: Programmes for upgrading management skills and practices, OECD Publishing, Paris.

OECD (2016d), "The Relationship Between GVCs and Productivity”, background paper by Criscuolo, C., J. Timmis and N. Johnstone for the Global Forum on Productivity, http://oe.cd/GFPLisbon

OECD (2017), Integrity Review of Mexico: Taking a Stronger Stance Against Corruption, OECD Publishing, Paris..

OECD and World Bank Group (2015), "Inclusive Global Value Chains Policy options in trade and complementary areas for GVC Integration by small and medium enterprises and low-income developing countries". Report prepared for submission to G20 Trade Ministers Meeting Istanbul, Turkey, 6 October 2015.

Palumbo, G. et al. (2013), "Judicial performance and its determinants: a cross-country perspective", OECD Economic Policy Papers, No. 5.

Sandoval, S. (2015), “The Distribution of Top Incomes in Mexico: How rich are the richest?”, Paris School of Economics. Public Policy and Development Master's Thesis, http://piketty.pse.ens.fr/files/Sandoval2015.pdf

Taglioni, D. and D. Winkler (2014), "Making Global Value Chains Work for Development", Economic premise No. 143. World Bank, Washington, DC.

UNESCAP (2014), "Trade facilitation and Paperless Trade Implementation in Asia: Highlights from UN ESCAP's research", presentation at 10th East Asian Institutes Forum "Global Value Chains and East Asian Economic Integration", 9 October 2014.

Watkins R. (2007), "El Reto de China a las Manufacturas de México" en Dussel E., Oportunidades en la relación económica y comercial entre China y México, CEPAL. 